\title{
Greece: 2007 Article IV Consultation-Staff Report; Staff Supplement; Public Information Notice on the Executive Board Discussion; and Statement by the Executive Director for Greece
}

Under Article IV of the IMF's Articles of Agreement, the IMF holds bilateral discussions with members, usually every year. In the context of the 2007 Article IV consultation with Greece, the following documents have been released and are included in this package:

- $\quad$ The staff report for the 2007 Article IV consultation, prepared by a staff team of the IMF, following discussions that ended on January 25, 2008, with the officials of Greece on economic developments and policies. Based on information available at the time of these discussions, the staff report was completed on March 20, 2008. The views expressed in the staff report are those of the staff team and do not necessarily reflect the views of the Executive Board of the IMF.

- $\quad$ A staff supplement of April 15, 2008, updating information on recent developments.

- $\quad$ A Public Information Notice (PIN) summarizing the views of the Executive Board as expressed during its April 18, 2008 discussion of the staff report that concluded the Article IV consultation.

- $\quad$ A statement by the Executive Director for Greece.

The document listed below has been or will be separately released.

Selected Issues Paper

The policy of publication of staff reports and other documents allows for the deletion of market-sensitive information.

\author{
Copies of this report are available to the public from \\ International Monetary Fund • Publication Services \\ $70019^{\text {th }}$ Street, N.W. • Washington, D.C. 20431 \\ Telephone: (202) 623-7430 • Telefax: (202) 623-7201 \\ E-mail: publications@imf.org • Internet: http://www.imf.org
}

Price: $\$ 18.00$ a copy

\section{International Monetary Fund Washington, D.C.}





\section{INTERNATIONAL MONETARY FUND}

\section{GREECE}

\section{Staff Report for the 2007 Article IV Consultation}

Prepared by the Staff Representatives for the 2007 Consultation with Greece

Approved by Alessandro Leipold and Michael Hadjimichael

March 20, 2008

\section{EXECUTIVE SUMMARY}

- $\quad$ The Greek economy has been buoyant for several years and growth is expected to remain robust for some time. The risks to the outlook are tilted to the downside. In the near term, risks stem from a weaker external environment and a potential liquidity squeeze of banks. Over the longer-term, a persistent loss of competitiveness raises the prospect of a prolonged period of slow growth. Averting this risk requires improving cost competitiveness through wage moderation, an environment that encourages product upgrading, and a broadened effort to reform product and labor markets.

- The Greek banking sector appears to be sound and has thus far remained largely unaffected by the financial market turmoil. However, continued rapid credit growth and increasing presence in southeastern Europe (SEE), financed partly by wholesale funding, have increased banks' exposure to credit, country, and liquidity risks. Appropriate steps have been taken to strengthen supervision and foster cooperation with SEE supervisors, but stress testing needs to be upgraded.

- The authorities are pursuing further fiscal consolidation with the goal of achieving a balanced budget by 2010. Given the high level of public debt and anticipated aging pressures, further adjustment thereafter to a surplus position is necessary. Revenue objectives for 2008-10 are ambitious; their achievement will require further revenue enhancing measures. Reforms to tax administration and expenditure management are being implemented, and will need to be broadened.

- A gradualist approach is being taken on pension reform. The reform agenda is narrow and the policy proposals are lacking full assessment of financing needs and cost savings. While staff sees a need for greater ambition, the authorities view their reform strategy as politically realistic.

- $\quad$ Structural reforms have been put in place, but impediments to higher productivity remain. Important initiatives are underway to improve the business environment. However, enhancing competition and reducing labor market rigidities remain challenges. 
Executive Summary 1

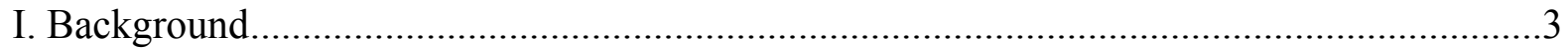

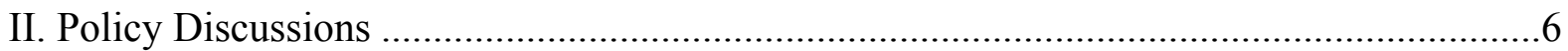

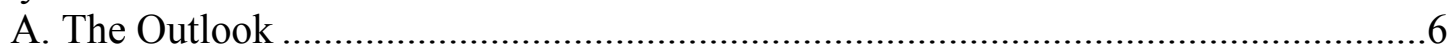

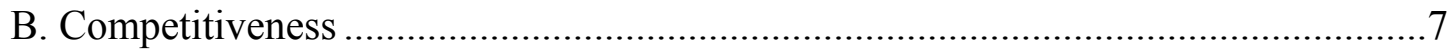

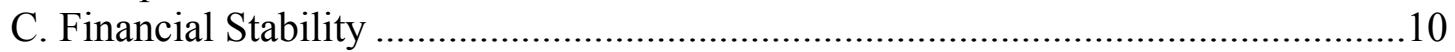

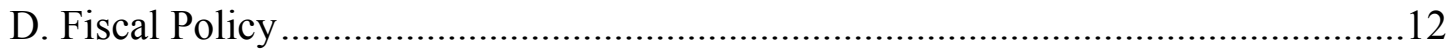

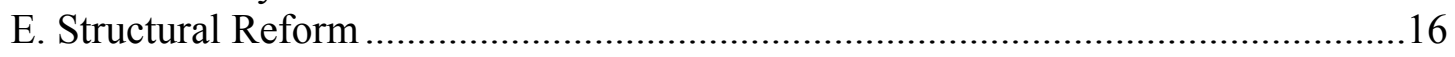

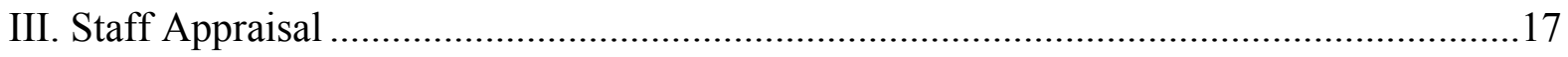

Tables

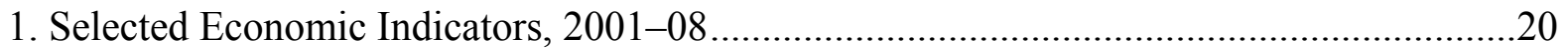

2. Macroeconomic Framework, 2001-10 .........................................................................21

3. Medium-Term Baseline Scenario, 2004-13 ...............................................................22

4. Summary of Balance of Payments, 2004-13 …...........................................................23

5. Core Set of Financial Soundness Indicators for Deposit-Taking Institutions,

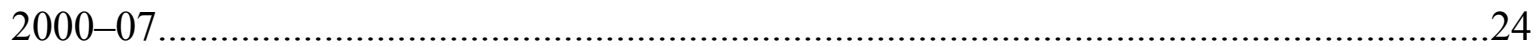

6. Encouraged Set of Financial Soundness Indicators, 2000-07 .........................................25

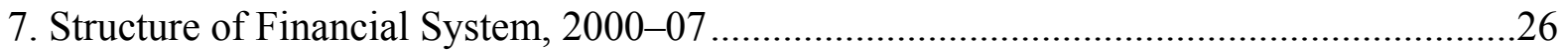

8. Indicators of External and Financial Vulnerability, 2001-07 .......................................27

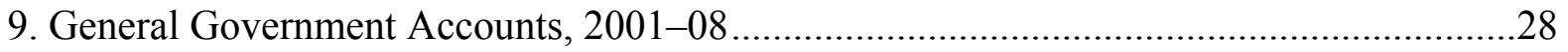

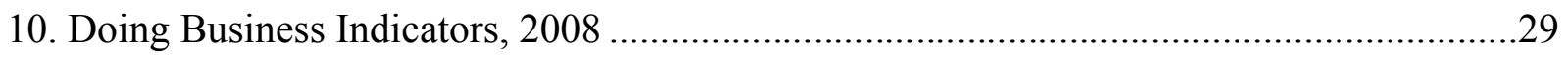

Figures

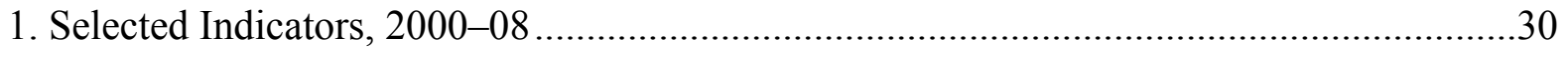

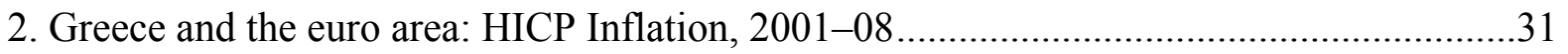

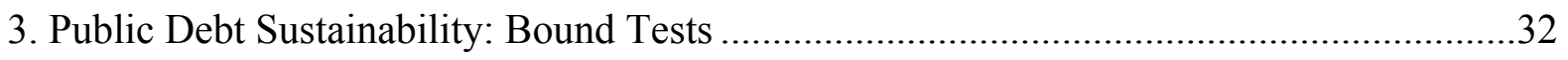

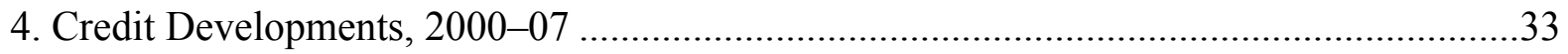

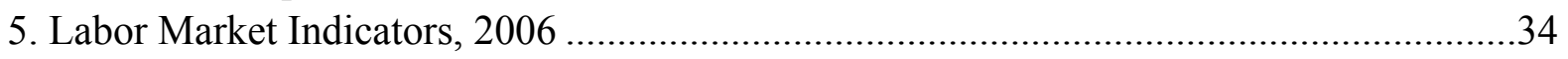

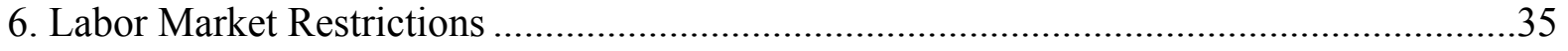

7. Product Markets Restrictiveness Indicators.................................................................. 36

Boxes

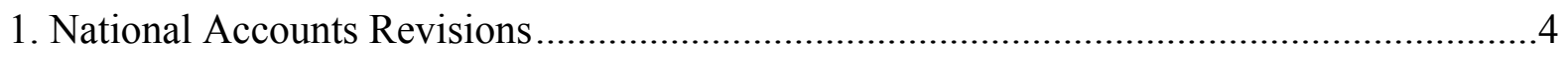

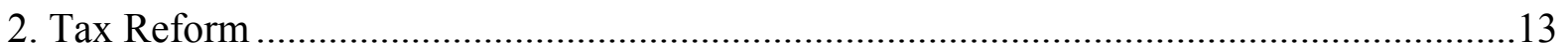

Appendices

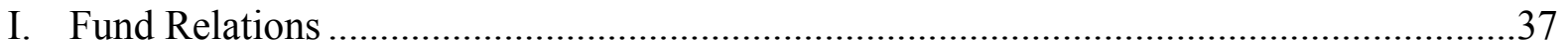

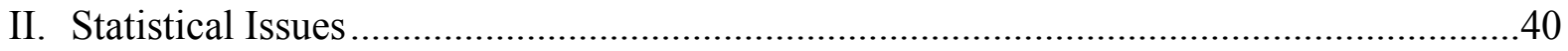




\section{BACKGROUND}

1. The Greek economy has been buoyant for several years, and the gap in real per capita income between Greece and the EU-15 has narrowed significantly. Real GDP growth averaged $4 \frac{1}{4}$ percent during $2000-06$, and is estimated at 4 percent in $2007 .{ }^{1}$ Solid gains in employment and handsome real wage increases have underpinned strong consumption growth. Rapid credit expansion that followed financial sector liberalization and the drop in interest rates associated with euro adoption have fostered rising residential investment by households, while strong profitability has fueled corporate sector investment. However, the external sector has been a drag on

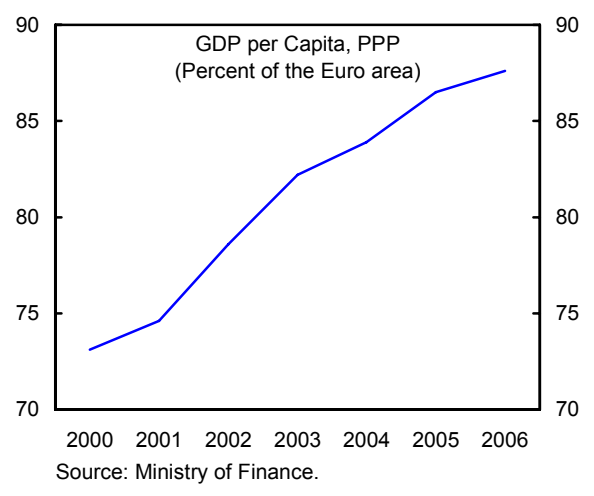
growth; external imbalances have remained large throughout and widened (Figure 1, Tables 1 and 2).

\section{Sustaining the strong growth momentum over the longer-term will require addressing several challenges.}

- $\quad$ Rising labor costs are a threat to competitiveness and may ultimately act as a brake on investment and employment growth. A substantial narrowing of the external current account deficit is needed to stabilize the net foreign asset position.
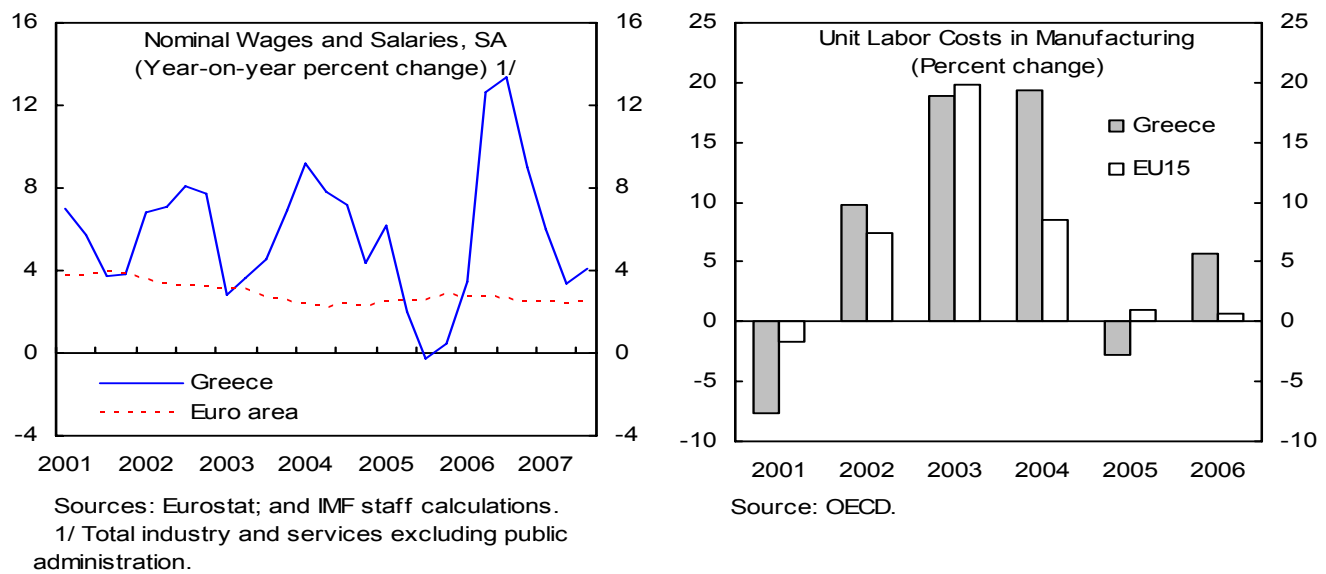

\footnotetext{
${ }^{1}$ The analysis in this report is based on the revised national accounts data (see Box 1). There are large differences between national accounts and settlements-basis balance of payments data that are not easily reconciled (see Box in Appendix II).
} 


\section{Box 1. National Accounts Revisions}

EU regulation stipulates that member states change the base year for the national accounts at least once every five years. For that purpose, and to resolve a number of reservations raised by Eurostat regarding previous estimates, the National Statistical Service of Greece (NSSG) carried out an in-depth revision of the national accounts with 2000 as the new base year. The revision utilized new statistical data sources - in particular, the 2001 population census; an update of the family budget survey; new surveys of enterprises in construction, hotels, retail and wholesale commerce, and transport; and new estimates of rents, capital stock, and depreciation. In October 2006, the NSSG announced a provisional increase of 25.7 percent in the GDP level. However, following a review by Eurostat, the final revision involves an increase in 2000 GDP of 9.6 percent.

While real growth rates remain roughly the same as those for the old GDP series, the composition of growth is different. In particular, gross fixed investment and private consumption are now estimated to be stronger while imports are a larger drag on growth. ESA95-basis unemployment rate is estimated to be lower in the revised national accounts framework.

\begin{tabular}{|c|c|c|c|c|c|c|}
\hline & 2000 & 2001 & 2002 & 2003 & 2004 & 2005 \\
\hline \multicolumn{7}{|c|}{ GDP at current prices (billions of euro) } \\
\hline Old & 124.4 & 133.1 & 143.5 & 155.5 & 168.4 & 181.1 \\
\hline New & 136.3 & 146.3 & 157.6 & 171.3 & 185.2 & 198.6 \\
\hline Difference (percent) & 9.6 & 9.9 & 9.8 & 10.1 & 10.0 & 9.7 \\
\hline \multicolumn{7}{|l|}{ Real GDP growth (percent) } \\
\hline Old & $\ldots$ & 5.1 & 3.8 & 4.8 & 4.7 & 3.7 \\
\hline New & $\cdots$ & 4.5 & 3.9 & 5.0 & 4.6 & 3.8 \\
\hline \multicolumn{7}{|c|}{ Difference in contributions to GDP growth (percentage points) $1 /$} \\
\hline Domestic demand & $\cdots$ & -0.5 & 0.2 & 1.3 & 0.5 & 0.8 \\
\hline Private consumption & $\cdots$ & 0.8 & 0.5 & 0.5 & 0.2 & 0.7 \\
\hline Public consumption & $\cdots$ & 0.0 & 0.2 & 0.0 & 0.1 & 0.1 \\
\hline Gross fixed investment & $\ldots$ & -0.7 & 0.9 & 0.1 & 0.0 & 0.6 \\
\hline Net foreign demand & $\cdots$ & -0.1 & -0.1 & -1.1 & -0.6 & -0.7 \\
\hline Exports of goods and services & $\ldots$ & -0.4 & 0.1 & 0.3 & 0.1 & -0.1 \\
\hline Imports of goods and services & $\ldots$ & -0.3 & 0.2 & 1.4 & 0.7 & 0.6 \\
\hline \multicolumn{7}{|l|}{ Unemployment rate (percent) } \\
\hline Old & 11.7 & 11.2 & 10.9 & 10.4 & 11.0 & 10.4 \\
\hline New & 11.0 & 10.4 & 9.9 & 9.4 & 10.2 & 9.5 \\
\hline
\end{tabular}

Sources: Ministry of Finace; National Statistical Service of Greece; and IMF staff calculations.

1/ New minus old. 
- Inflation inertia - around 3-31/2 percent in recent years - and the persistence of an inflation differential with the euro area (Figure 2), while partly driven by the convergence process, are also symptomatic of rigidities in the labor and product markets.

- Immigration, an important source of labor supply

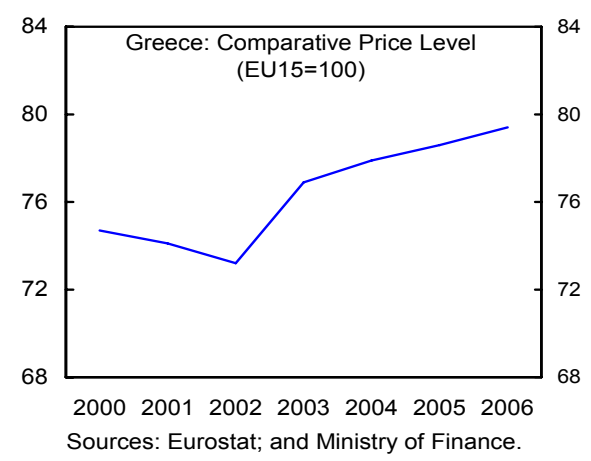
during the past few years, has begun to wane. Employment growth will depend increasingly on the mobilization of the large unused potential labor input.

- $\quad$ The current high level of government debt (93 percent of GDP) and the projected increases in pension and health care costs related to population aging will adversely affect debt sustainability. In addition, the rigidity of the expenditure structure renders the budget vulnerable to shocks that could result in a sharp growth slowdown (Figure 3).

- $\quad$ The persistence of high nonperforming loans (NPLs) in the face of rapid credit growth, the rising exposure of Greek banks in southeastern Europe (SEE), and their growing reliance on wholesale funding suggest increasing exposure of banks to credit and liquidity risk. However, with household indebtedness still relatively low, strong credit growth can be expected to continue (Figure 4).

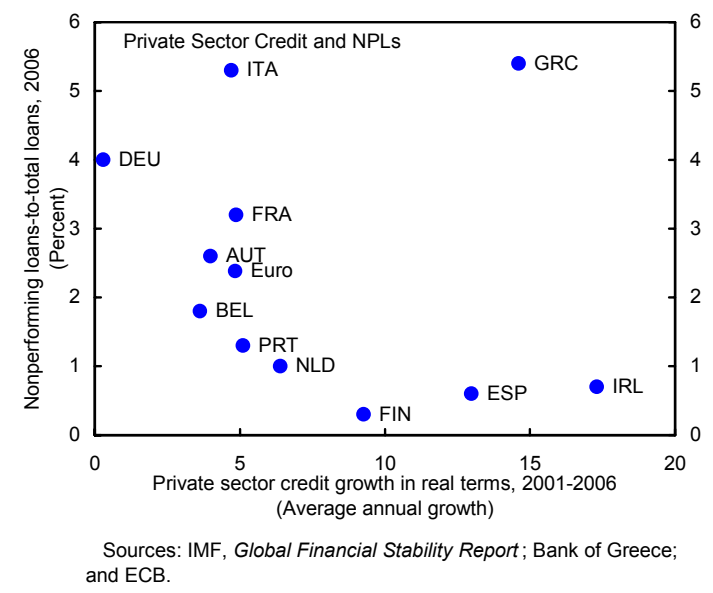

3. The authorities are seeking to address some of these challenges, and will need to persevere with and broaden the reform efforts. The deterioration in the public finances in the period leading up to the 2004 Olympic Games has been reversed, in compliance with the Stability and Growth Pact's excessive deficit procedure. The general government deficit fell by about 5 percentage points of GDP over two years to $2 \frac{1}{2}$ percent of GDP in 2006, and was contained at $2 \frac{3}{4}$ percent of GDP in 2007 despite several unexpected one-off expenditures amounting to about 1 percent of GDP. Also, measures have been initiated under the National Reform Program for 2005-08 to strengthen tax administration and expenditure management, enhance performance of state-owned enterprises, improve the business environment and facilitate private sector development. 


\section{Policy Discussions}

4. Against this backdrop, the 2007 Article IV consultation discussions focused on policies needed to maintain domestic economic and financial stability, through vigilance over financial sector risks, steps to ensure long-term fiscal sustainability, and reforms to tackle the structural constraints to sustained growth.

\section{A. The Outlook}

\section{Economic growth is expected to moderate in the near term but should remain} solid on the back of continued strong domestic demand. Although the pent-up demand for housing is anticipated to fade, the investment outlook appears positive on account of healthy corporate balance sheets, execution of projects benefiting from government incentives and public-private partnerships, and absorption of EU funds under the Community Support Framework. Consumer demand is also expected to remain robust. Thus, on the basis of the Autumn 2007 common external assumptions of the European Commission, the authorities' baseline scenario projects real GDP growth as remaining sustained at around 4 percent during 2008-10. ${ }^{2}$ However, the subsequent deterioration in the external environmenthigher oil prices, the financial turmoil and associated slowdown in main partner countries, and a stronger euro - will dampen Greece's growth prospects. Accordingly, staff project GDP growth slowing down to 3.7 percent in 2008, and averaging 31/2 percent during 2009-10 (Table 3$).^{3}$

Macroeconomic Projections, 2007-10

(Percentage changes, unless otherwise indicated)

\begin{tabular}{|c|c|c|c|c|c|c|c|}
\hline & \multirow{2}{*}{$\begin{array}{l}2007 \\
\text { Staff } \\
\text { Est. }\end{array}$} & \multicolumn{2}{|c|}{2008} & \multicolumn{2}{|c|}{2009} & \multicolumn{2}{|c|}{2010} \\
\hline & & MoF 1/ & Staff & MoF 1/ & Staff & MoF 1/ & Staff \\
\hline Real GDP & 4.0 & 4.0 & 3.7 & 4.0 & 3.5 & 4.0 & 3.6 \\
\hline Total domestic demand & 4.9 & 4.7 & 4.4 & 4.4 & 3.9 & 4.3 & 4.1 \\
\hline Net exports (contribution to growth) & -1.7 & -1.4 & -1.3 & -1.1 & -1.1 & -1.0 & -1.2 \\
\hline Exports of goods and services & 7.6 & 7.3 & 6.6 & 7.6 & 6.6 & 7.7 & 6.5 \\
\hline Imports of goods and services & 9.1 & 7.8 & 7.2 & 7.2 & 6.4 & 7.0 & 6.6 \\
\hline Current account (percent of GDP) 2/ & -14.6 & -14.4 & -15.0 & -14.2 & -14.8 & -13.9 & -14.7 \\
\hline \multicolumn{8}{|l|}{ Memorandum items: } \\
\hline Growth of relevant foreign markets & 8.4 & 7.5 & 7.2 & 7.1 & 6.7 & 7.5 & 6.5 \\
\hline Unit labor cost & 3.8 & 3.1 & 3.4 & 2.7 & 3.0 & 2.6 & 2.9 \\
\hline Unemployment rate $3 /$ & 7.8 & 6.8 & 7.0 & 6.3 & 6.7 & 6.0 & 6.4 \\
\hline
\end{tabular}

Sources: National Statistical Service; Ministry of Economy and Finance; and IMF staff projections.

1/ Authorities' baseline scenario as specified in the December 2007 SGP update.

2/ National accounts basis.

3/ ESA95 basis.

2 See "The 2007 Update of the Hellenic Stability and Growth Program 2007-2010", December 2007. http://www.mnec.gr/export/sites/mnec/en/economics/growth_programme_2005-8/2008_01_09_SGP-GREN_07.pdf

${ }^{3}$ This is broadly similar to the authorities' alternate scenario in the SGP update report. 


\section{The risks to the staff projections are tilted to the downside, stemming from} possible persistence of the global financial turmoil. Such a persistence could result in a liquidity squeeze for banks dependent on wholesale funding and prompt them to scale back business plans (see $\llbracket 14$ ). The persistence of the turmoil also could hit export prospects harder than presumed in the baseline scenario.

\section{The authorities see ample scope for sustained growth over the longer term} through reaping the benefits from Greece's location and becoming a regional business hub. In this context, they highlight the ongoing and planned investment in infrastructure. An expansion of the Greek shipping fleet and construction of several large-scale energy interconnection projects in the natural gas, electricity and oil sectors are underway. The authorities' strategy also entails developing ports, rail and road systems, and tourist infrastructure through private participation. They agree that realizing the investment and growth potential would require pressing ahead with structural reforms that create a conducive policy environment and improved competitiveness.

\section{Inflationary pressures picked up in Q4-2007 owing to rising food and oil prices,} and the risks are to the upside. The authorities, concerned about the possible emergence of second-round effects, have appealed to social partners and entrepreneurs to exercise restraint in wage and price-setting. They were encouraged, however, by the narrowing of the inflation differential with the euro area during 2007, and saw it as a sign of reduced structural rigidities. Assuming no significant second-round effects and oil prices in line with the World Economic Outlook projections, staff project average inflation to rise to 3.3 percent in 2008 and to moderate slightly thereafter.

\section{B. Competitiveness ${ }^{4}$}

\section{A range of standard indicators point to a steady deterioration in competitiveness vis-à-vis trading partners.}

Competitiveness, as measured by Greece's CPI-based and ULC-based real effective exchange rate, has deteriorated
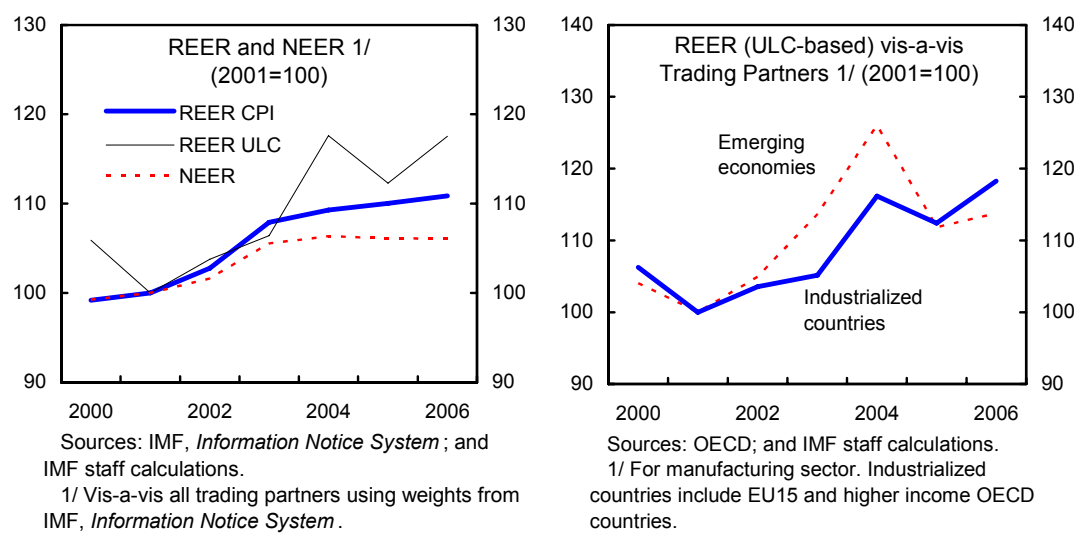

\footnotetext{
${ }^{4}$ As Greece is a member of a currency union, the assessment of external stability is reserved for the union as a whole, and the staff report assesses only trends in competitiveness and balance of payments developments. The euro at present appears to be on the strong side relative to medium-term fundamentals.
} 
by about 10 percent and 17 percent, respectively, since EMU accession in 2001. Staff estimates of competitiveness based on CGER methodologies also suggest a sizable gap in the range of $30-40$ percent in $2007 .^{5}$

\section{The authorities recognized the negative implications of the steady deterioration} of competitiveness, but did not consider it an impediment in the near term. They observed that Greek enterprises were restructuring and moving up the technology ladder and that developments in employment and unemployment had been favorable. Reflecting this and the increasing diversification of trade toward the rapidly growing countries in SEE, Greece's export market share has been broadly maintained since EMU entry in 2001. National accounts data suggest a continuation of strong export performance in 2007, though bank settlements data point to a substantial slowdown in the second half. The authorities further noted that services exports were expanding rapidly, and they saw promising prospects for sustained growth in this area.
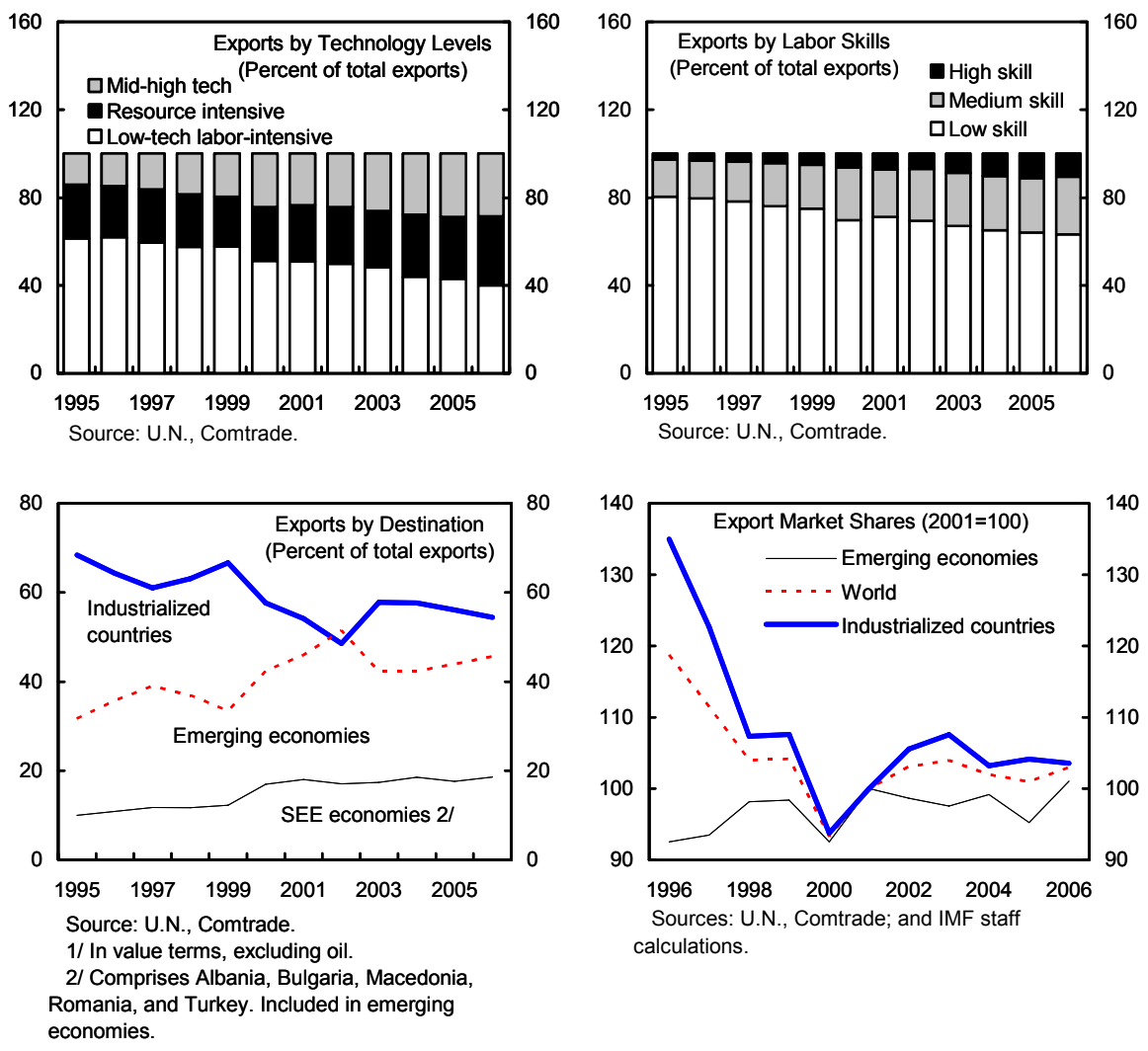

\footnotetext{
${ }^{5}$ See Methodology for CGER Exchange Rate Assessments, IMF, 11/8/06, http://www.imf.org/external/np/pp/eng/2006/110806.pdf. Given the weaknesses in Greece's external sector data, these estimates have to be treated with caution. Greece's competitiveness is also discussed in the accompanying Selected Issues paper and in "Competitiveness in the Southern Euro Area: France, Greece, Italy, Portugal, and Spain". The latter accompanying paper is a collection of cross-country studies prepared as background material for the consultations with each of the countries covered.
} 
11. Staff underscored the risks to the external outlook. The higher value-added goods are primarily exported to EU countries while exports to neighboring markets mostly include low-tech laborintensive goods. Thus, Greek exporters are likely to face growing competition as these neighboring countries seek greater integration with other EU countries. Also,
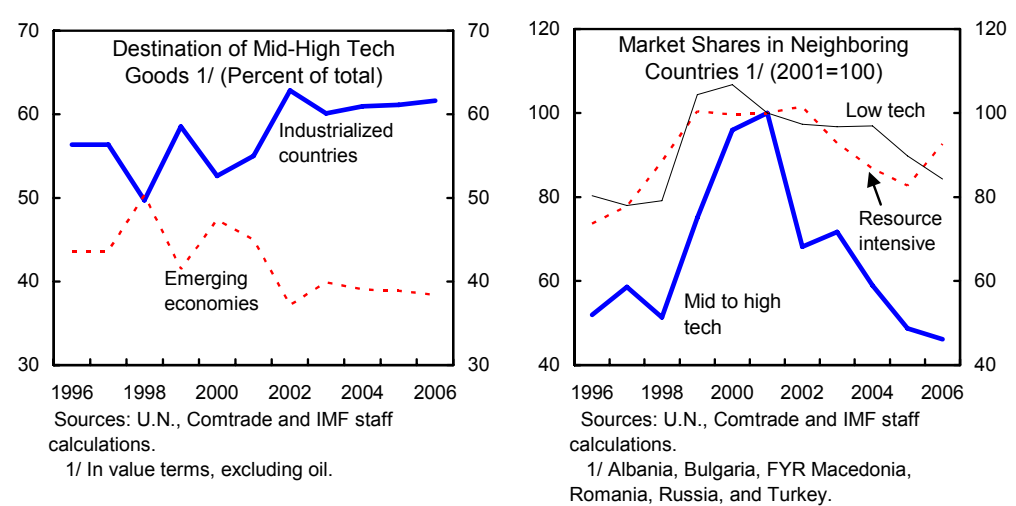
many export-oriented labor-intensive manufacturing firms are increasingly relying on outsourcing. ${ }^{6}$ Staff further noted that rising labor costs above productivity gains are adversely affecting the profitability of the tourism sector which faces intense price competition. Accordingly, staff stressed the importance of early efforts to improve cost competitiveness through wage moderation and strong productivity growth, and to create an environment conducive to investment in product upgrading.

\section{There was broad agreement that the current account deficit would remain}

relatively large in the medium term. It is assumed that, in line with recent trends, merchandise export market share will be maintained through product upgrading and geographic diversification. For its part, the shipping sector should gain market share with the expansion of the fleet. Import growth is likely to remain robust in view of the substantial investment and new ships purchases in the pipeline. Accordingly, the current account deficit is projected to remain around 14 percent of GDP during 2008-10 and fall slightly thereafter once the outlays on new ships fade away (Table 4). Thus, Greece's already large negative international investment position will deteriorate further.

Current Account Balance, 2004-13 1/

\begin{tabular}{lrrrrrrrrrr}
\multicolumn{10}{c}{ (Percent of GDP) } \\
\hline & 2004 & 2005 & 2006 & 2007 & 2008 & 2009 & 2010 & 2011 & 2012 & 2013 \\
\hline Current account & -5.8 & -7.4 & -11.1 & -13.8 & -13.9 & -14.1 & -13.9 & -12.9 & -12.6 & -12.7 \\
$\quad$ Excluding oil & -3.4 & -4.0 & -7.0 & -10.0 & -9.6 & -10.1 & -10.0 & -9.2 & -9.0 & -9.2 \\
Excluding ships & -5.9 & -7.0 & -9.5 & -11.4 & -11.3 & -11.5 & -11.8 & -12.0 & -12.3 & -12.6 \\
Excluding oil and ships & -3.4 & -3.7 & -5.4 & -7.6 & -7.0 & -7.5 & -8.0 & -8.3 & -8.7 & -9.2 \\
Trade balance & -5.4 & -6.1 & -9.3 & -10.7 & -11.3 & -11.4 & -11.0 & -9.9 & -9.5 & -9.5 \\
$\quad$ Of which: goods & -13.7 & -13.9 & -16.5 & -17.9 & -18.9 & -19.1 & -18.8 & -17.9 & -17.5 & -17.6 \\
$\quad$ Excluding oil and ships & -11.4 & -10.2 & -10.8 & -11.6 & -12.1 & -12.5 & -12.9 & -13.3 & -13.7 & -14.1 \\
$\quad$ Services & 8.4 & 7.8 & 7.2 & 7.3 & 7.7 & 7.8 & 7.8 & 7.9 & 8.0 & 8.1 \\
Income balance & -2.4 & -2.9 & -3.3 & -3.9 & -4.0 & -4.2 & -4.4 & -4.6 & -4.7 & -4.8 \\
Transfers (net) & 2.0 & 1.6 & 1.6 & 0.7 & 1.4 & 1.5 & 1.5 & 1.6 & 1.6 & 1.6 \\
\hline
\end{tabular}

Sources: Bank of Greece; National Bank of Greece; and IMF staff projections.

1/ Projection for 2008-13.

\footnotetext{
${ }^{6}$ European Commission, Sectoral Study 32/05, 2005.
} 

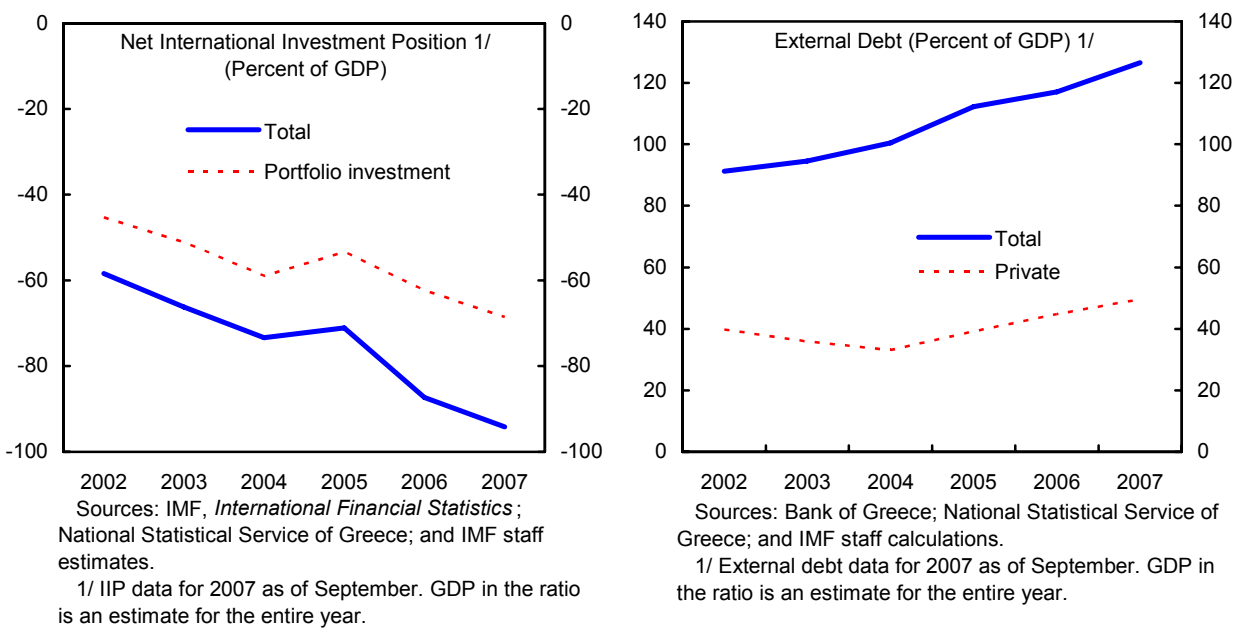

13. In view of Greece's EMU membership, the availability of external financing is not a concern, but the correction of cumulating indebtedness could weigh appreciably on growth going forward. While the risk of transmitting vulnerabilities to the euro area is very small reflecting Greece's small relative size, ${ }^{7}$ large persistent current account deficits would increase the vulnerabilities to a reversal in market sentiment, leading to a corrective retrenchment of private sector balance-sheets in the face of rising indebtedness, and a possible appreciable rise in the cost of funding over time. These developments would have significant negative implications for growth.

\section{Financial Stability}

\section{The spillover effects from the global financial turmoil on the Greek banking} system have been limited thus far. Balance sheet and off-balance sheet exposures of Greek banks to the United States subprime mortgage sector are marginal. Greek banks are not liquidity providers for asset-based commercial paper conduit programs. Despite the growing reliance on wholesale funding, banks have not yet felt the impact from the global credit pressures as they had prefunded their operations up to the first half of $2008 .^{8}$
Sources of Funding of Banks

(Percent of total funding, end of period)

\begin{tabular}{lrrr}
\hline & 2005 & 2006 & $2007 Q 3$ \\
\hline Wholesale funding & 27.3 & 27.7 & 28.9 \\
$\quad$ Of which : repos & 7.7 & 6.2 & 4.4 \\
Retail funding & 65.4 & 62.2 & 59.9 \\
Other 1/ & 7.3 & 10.1 & 11.2 \\
\hline
\end{tabular}

Source: Bank of Greece.

$1 /$ It includes shareholders equity and securitized loans. However, funding and roll over risks could be heightened if the financial turmoil were to persist. The Bank of Greece (BoG, the banking

\footnotetext{
${ }^{7}$ Greece's current account deficit accounts for only 0.3 percent of euro area GDP.

${ }^{8}$ However, the stock prices of Greek banks have, on average, fallen by nearly 25 percent from the peak in November 2007.
} 
supervisor) is monitoring banks' liquidity positions closely. BoG staff indicated that while banks could temporarily bridge their financing needs through repos, they should not resort to this mode of bridge financing on a long-term basis to sustain their ongoing operations. In fact, some banks have

reportedly

started to scale

back their

business plans in recognition of the new liquidity environment and rising funding costs. Greece's submission for
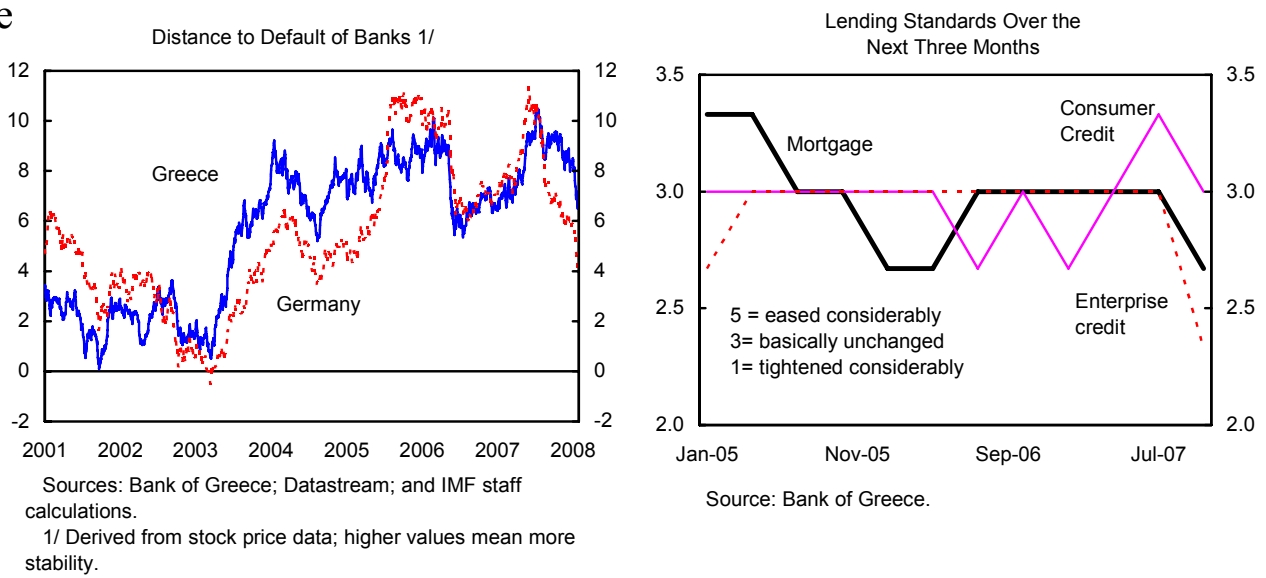
the euro area lending survey suggests that some credit tightening is likely in the coming months, particularly for credit to enterprises.

\section{The Greek banking system remains healthy, adequately capitalized, and highly} profitable, but key risks will need to be monitored closely (Tables 5-7). Continued rapid credit growth - averaging 20 percent annually — has increased banks' exposure to credit risk and their vulnerability to swings in the economic cycle. NPL ratios have been persistently high, suggesting that banks' risk management systems may need further improvement (Table 8). In addition, the increasing exposure in SEE, while entailing significant benefits, carries foreign exchange, credit, and country risks. Recent stress tests suggest that banks are resilient to a range of possible adverse shocks. However, staff observed that the stress tests did not take into account correlation of risks and that the underlying quality of loan portfolio was uncertain as it had not been tested through a complete economic cycle. The BoG agreed that upgrading of stress testing was necessary and indicated that steps had been taken to strengthen supervision through increasing provisioning requirements

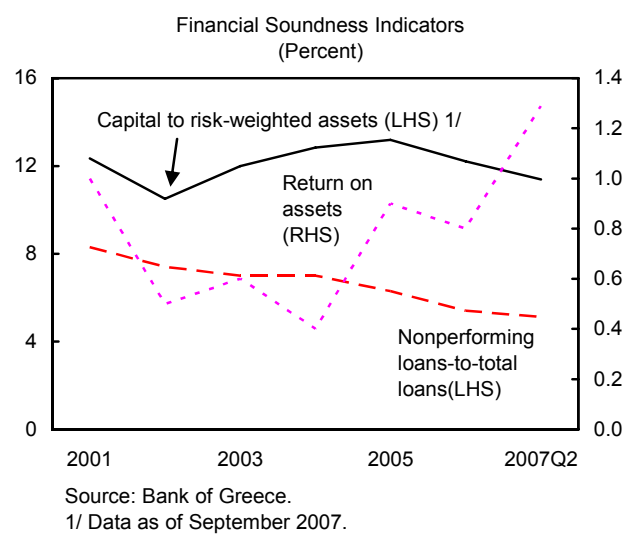
Banks: Exposures and Market Shares in Southeastern Europe

\begin{tabular}{|c|c|c|c|c|c|c|}
\hline \multicolumn{7}{|c|}{ (Percent) } \\
\hline & \multicolumn{3}{|c|}{ Exposures 1/ } & \multicolumn{3}{|c|}{ Market shares } \\
\hline & 2005 & 2006 & $2007 \mathrm{H} 1$ & 2005 & 2006 & 2007H1 \\
\hline Albania & 0.2 & 0.2 & 0.3 & 17.5 & 19.0 & 22.0 \\
\hline Bulgaria & 1.3 & 1.9 & 2.0 & 19.9 & 23.6 & 28.6 \\
\hline FYROM & 0.2 & 0.2 & 0.3 & 26.8 & 32.3 & 27.7 \\
\hline Romania & 2.0 & 2.7 & 3.2 & 11.6 & 14.4 & 15.1 \\
\hline Serbia & 0.4 & 0.9 & 1.1 & 10.5 & 18.7 & 16.6 \\
\hline Turkey & 0.3 & 4.5 & 4.8 & 0.0 & 3.9 & 3.8 \\
\hline
\end{tabular}

Source: Bank of Greece.

$1 /$ In percent of total assets. and seeking a tightening of lending standards. 
16. Cross-border banking supervision is being stepped up amid heightened concerns over the potential consequences of a deceleration in global growth rates. Nine SEE supervisory authorities have agreed to intensify collaboration on achieving convergence of supervisory practices, including those related to risk assessment, money laundering and financing of terrorism. ${ }^{9}$ Regarding exposures of Greek banks abroad, the BoG has adopted a risk-based, multilayer supervisory framework, which includes on-site examinations and setting country limits. The Basel II framework is scheduled to be introduced in March 2008, and steady progress is being made in implementing the EU's capital requirement Directives.

\section{Other aspects of the regulatory and supervisory framework are also being} addressed. The Private Insurance Supervisory Committee (PISC) became operational in January 2008, and is adopting a risk-based approach to insurance supervision. The authorities have taken some measures to address the deficiencies identified during the FATF assessment in relation to the legal and supervisory frameworks for anti-money laundering and combating financial terrorism. However, the remedial program being adopted by the authorities cannot be finalized until a new law is in effect and relevant regulatory instruments are developed. Staff urged the authorities to proceed quickly with the necessary staffing of the PISC and related changes in legislation so that there are no supervisory gaps, and to intensify efforts to achieve prompt compliance with the FATF standards.

\section{Fiscal Policy}

\section{The authorities are pursuing further fiscal consolidation with the goal of} achieving a balanced budget by 2010. The 2008 budget aims to reduce the general government deficit to 1.6 percent of GDP through revenue measures (Table 9). Revenue efforts will center on combating tax evasion through administrative measures, restructuring taxation of heating oil, and reform of property taxes (Box 2). The saving in expenditure from the elimination of the one-off expenditures incurred in 2007 will be offset by higher outlays on wages and social transfers - the latter has increased as ratio to GDP by 0.6 percentage point every year since 2005 and this trend will continue in 2008, making the expenditure structure more rigid. The authorities expected fiscal consolidation in 2009-10 also to be achieved from higher revenues, but have not specified the enabling measures. Saving from improvements in expenditure management would be directed toward further reinforcing the social welfare system, especially increasing targeted support to poor households. The authorities also observed that achievement of a balanced budget by 2010 might not be feasible if the pace of economic growth slowed in line with the staff scenario. Staff stressed that further fiscal adjustment to a surplus position over the medium term was necessary to

\footnotetext{
${ }^{9}$ A multilateral memorandum of understanding was signed in July 2007 and is being followed up.
} 


\section{Box 2. Tax Reform}

The authorities have taken several steps since 2004 to simplify the tax system, broaden the base, and tackle tax evasion. Specifically, they unified the taxation of interest income, eliminated tax exemption on retained earnings, raised the VAT rate and extended it to real estate transactions, lowered taxes for individuals and businesses, and strengthened tax administration. The tax reform in 2008 builds on these efforts, and includes:

Personal income tax cuts. The two middle marginal tax rates of 29 percent and 39 percent will be reduced by 2 percentage points annually in 2008-09 to 25 percent and 35 percent, respectively.

Rationalizing real estate taxation. The inheritance and parental gift tax on properties of less than euro 90,000 and the real estate tax on large properties are being abolished. These will be replaced by a uniform 1 percent duty on property transfers and a new tax on individual's property ( 0.1 percent) and on legal entities' property ( 0.6 percent). Rural properties and first homes below 200 square meters and less than euro 300,000 in value are exempt from tax.

Harmonizing gasoil taxation. To curb widespread excise fraud, the authorities will eliminate the large differential in gasoil excise rates for heating and propellant use, and reform its distribution system. To limit the adverse impact, a program for compensating households will be introduced.

Improving tax compliance. A new Law on Tax Evasion passed in November 2007 provides for: the establishment of a National Council to guide efforts at combating tax fraud and evasion; strengthening the structure of tax administration; tax deductions for taxpayers who submit receipts for services; and the creation of a tax policy unit in the Ministry of Economy and Finance.

Estimated revenue impact. The total revenue impact of the above-mentioned measures in the 2008 budget is about 1 percent of GDP. (The authorities have not provided precise revenue impact of the individual measures). The estimate is subject to downside risks. There is uncertainty relating to the new property tax, especially as property registers remain to be fully updated. The revenue impact of the new tax evasion law is likely to be limited in the short term. 
safeguard debt sustainability in the event of shocks ${ }^{10}$ and as growth eventually slowed, and in view of the prospective large aging costs - according to the latest estimates dating from the 2002 stability programme update, pension spending would rise by some $10 \frac{1}{4}$ percent of GDP by $2050 .^{11}$

\begin{tabular}{|c|c|c|c|c|c|c|}
\hline \multicolumn{7}{|c|}{$\begin{array}{l}\text { General Government, 2005-10 } \\
\text { (Percent of GDP) }\end{array}$} \\
\hline & \multirow[t]{2}{*}{2005} & \multirow[t]{2}{*}{2006} & \multirow[t]{2}{*}{2007} & \multirow{2}{*}{$\begin{array}{c}2008 \\
\text { Budget }\end{array}$} & 2009 & 2010 \\
\hline & & & & & \multicolumn{2}{|c|}{ Staff Projection 1/ } \\
\hline Revenue & 38.0 & 39.5 & 39.9 & 41.1 & 41.7 & 42.3 \\
\hline Expenditure & 43.0 & 42.0 & 42.6 & 42.7 & 42.5 & 42.6 \\
\hline \multicolumn{7}{|l|}{ Of which: } \\
\hline One-off expenditures 2/ & 0.0 & 0.0 & 1.0 & 0.0 & 0.0 & 0.0 \\
\hline Social transfers & 16.0 & 16.6 & 17.2 & 17.8 & 18.0 & 18.5 \\
\hline General government balance & -5.1 & -2.5 & -2.7 & -1.6 & -0.9 & -0.3 \\
\hline Structural overall balance $3 /$ & -6.1 & -3.6 & -2.9 & -2.6 & -1.6 & -0.9 \\
\hline \multicolumn{7}{|l|}{ Memorandum item: } \\
\hline General government debt & 98 & 95 & 93 & 91 & 88 & 84 \\
\hline \multicolumn{7}{|c|}{ Sources: Ministry of Finance; and IMF staff calculations. } \\
\hline \multicolumn{7}{|c|}{$\begin{array}{l}\text { 1/ Broadly similar to the alternative scenario of the authorities. } \\
\text { 2/ Includes emergency assistance for the forest fire damage, cost of holding elections, settlement of debt to Olympic }\end{array}$} \\
\hline
\end{tabular}

\section{The revenue objectives for 2008-10 are ambitious, with associated risks to the}

fiscal deficit targets. However, the authorities emphasized that revenue developments would be monitored closely, and measures would be taken if necessary to meet the fiscal deficit target for 2008. Looking forward, staff recommended that the newly-established National Committee for tackling tax evasion focus attention on increasing tax compliance through simplifying tax laws and regulations, streamlining basic tax procedures, improving taxpayer services, and further intensifying risk-based auditing. Also, consideration should be given to increasing revenues through broadening the base of major taxes by phasing out distortionary exemptions ahead of any increases in tax rates, as statutory rates in Greece are already quite high. $^{12}$

\section{The authorities are continuing with efforts to strengthen public expenditure} management and broaden its scope. Measures are being put in place to introduce greater transparency and accountability in the operations and finances of local governments, public hospitals, and the pension funds through the adoption of standard budgeting and monitoring

${ }^{10}$ As Figure 3 shows, if real GDP growth dropped to 2 percent on average, the public debt-to-GDP ratio would rise to 98 percent by 2013, compared with a decline to 72 percent under the baseline scenario.

${ }^{11}$ Long-term projections of pension expenditure in accordance with EU methodologies are not available for Greece.

${ }^{12}$ See the accompanying background paper on "Broadening the Tax Base". 
frameworks. In the health sector, reforms are underway to consolidate the number of regional authorities, upgrade management of public hospitals, improve pricing and costing mechanisms, and introduce better controls on procurement. A pilot initiative in programbased budgeting has been launched for one line ministry in 2008, as a precursor to eventually integrating this approach fully into budget preparation and execution. Staff encouraged the authorities to also focus on developing a medium-term budget framework, extending the coverage of the budget, improving cash management, and putting in place an appropriate financial management information system. More generally, greater emphasis on effective and timely implementation of reforms was desirable. In this context, staff noted that because of slow progress in the preparatory organizational aspects of public enterprise reform there had been little improvement in enterprise performance during the past two years.

21. The authorities are following a gradualist approach on pension reform. ${ }^{13}$ Unless the social security system is fundamentally reformed, the long-term costs of population aging are expected to threaten the sustainability of the public finances. The completion of the actuarial studies of the major pension funds has been further delayed, and the authorities are proceeding with a narrowly focused reform agenda which is nonetheless already drawing considerable protest. They have ruled out reduction of the replacement rate and increases in the contribution rates. Instead, the focus is on obtaining efficiency gains through the merger of pension funds, tightening provisions for early retirement (the list of "heavy and unhealthy" occupations and the disability pension code would be reformed toward this end), increasing the incentives for people to stay employed longer, and tackling contribution evasion. In the absence of an assessment of the cost savings, it was not clear to what extent the current reform proposals would suffice to restore the pension fund to financial viability. Staff underscored the need for preparing and publishing detailed and realistic projections of the costs of population aging in accordance with EU methodologies, and preparing a comprehensive reform strategy on this basis. This would help promote an informed internal debate, needed to foster a consensus in favor of a more ambitious reform. Toward this end, staffing constraints and bureaucratic obstacles that have delayed data collection and analysis needed to be addressed urgently. Staff also argued that the gradualist approach being pursued would need deeper and more painful adjustments later, skew the tax burden toward future generations, and require larger fiscal surpluses to achieve debt sustainability. The authorities noted that their reform strategy was designed to be politically realistic.

\footnotetext{
${ }^{13}$ The last pension reforms in Greece were enacted in 2002. The details of that round of reform and issues in pension reform in Greece have been discussed earlier in IMF Country Reports 02/58 and 06/5.
} 


\section{E. Structural Reform}

\section{Sustaining strong economic growth with} domestic stability will require broader labor market reforms. A positive macroeconomic environment and some reforms - including easing overtime restrictions and reducing the disincentives to accept employment - have resulted in a steady increase in employment and a marked drop in the unemployment rate since 2000. Still, the labor market in Greece performs poorly by international standards. Unemployment remains one of the highest among

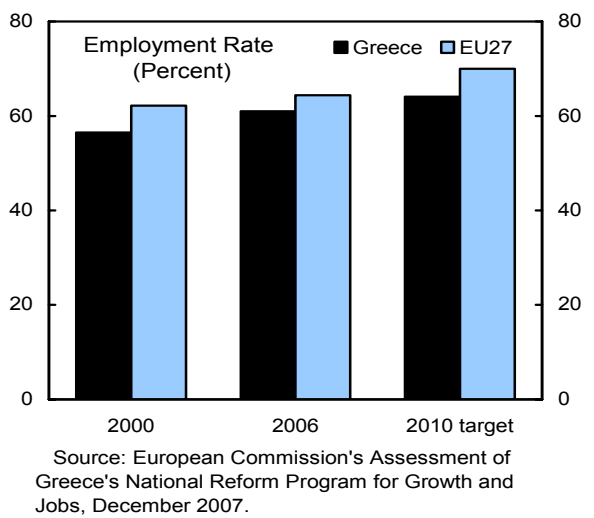
OECD countries, the employment rate is well below EU targets, and labor mobility is low (Figure 5). Greece is ranked 142 among 178 countries with regard to the regulation of employment in the World Bank's latest Doing Business report (Table 10). Against this background, staff urged the authorities to review employment protection legislation, especially on temporary employment. Staff also recommended strengthening active labor market policies to increase labor mobility.

23. Wage moderation and enhancing wage flexibility are important challenges. The authorities will continue with the policy of containing increases in basic wages of government employees and are hoping for a favorable signaling effect on private sector wage settlements. However, in recent years, wage increases in the private sector have been relatively large and often exceeded productivity growth. This is partly due to the links between minimum and average wage increases, and the administrative extension of collective agreements to enterprises not represented in the negotiations (Figure 6). The wage demands in the current round of collective bargaining appear to be following the same

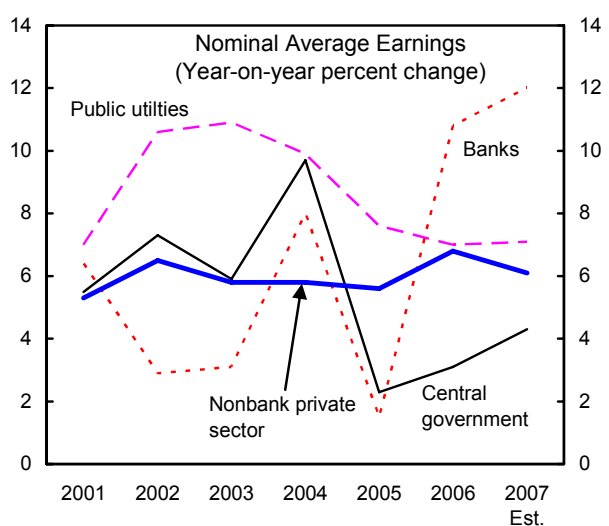

Source: Bank of Greece, Monetary Policy Report (October 2007). pattern, with adverse implications for preserving international cost competitiveness. The authorities explained that a reform of the collective bargaining system is not on their agenda as social consensus would be difficult to obtain simultaneously with consensus on pension reform.

\section{The authorities are seeking to improve the business environment through} economic incentives and strengthening of the institutional framework. The business sector is reaping the benefits of lower corporate tax rates, investment incentives for priority sectors, a new bankruptcy code, an updated company law, and simplified licensing of manufacturing businesses. The authorities are placing emphasis on reducing administrative 
burdens and improving the quality of services provision. Land use regulations are being updated to facilitate investment in renewable energy sources, tourism and industry. The authorities are also continuing with the privatization program - a partial stake in the savings bank and the telephone company was offered to institutional investors in 2007, and plans to privatize air and sea ports are being developed. However, Greece still fares poorly on the ease of doing business, with a rank of 100 among 178 countries, suggesting a need for further reform efforts. In this context, staff welcomed plans to introduce legislation in 2008 aimed at lessening bureaucracy in setting up businesses and sharply reducing business start-up time for commercial enterprises.

\section{Enhancing competition, particularly in the network industries and in the} transport sector, remains a challenge (Figure 7). The stake of the state in key public utilities remains high and price regulation is still pervasive. Unbundling of the operations of the incumbents in the electricity and gas markets and opening the transport market to new entrants should help foster competition in these sectors. Staff encouraged the authorities to tackle price rigidities in the broader product market by ensuring that the Hellenic Competition Commission is effectively organized and adequately staffed.

\section{STAFF APPRAISAL}

26. The Greek economy has performed well during the past several years. Economic activity has grown at a rapid pace, driven by strong domestic demand. Employment and unemployment indicators have improved markedly. Fiscal imbalances have been significantly reduced since 2004, and Greece exited from the EU's excessive deficit procedure in mid-2007. Structural reforms have been initiated to bolster fiscal performance and improve the business environment. While cost competitiveness has deteriorated steadily, the market share of goods exports has been maintained since EMU entry, owing to a move up the technology ladder and increasing geographic diversification of trade. However, the external sector has been a drag on growth, with large and widening current account deficits.

\section{Solid growth is expected to continue for some time, on the back of strong} domestic demand, but risks are tilted to the downside. In the near-term, the risks stem primarily from a possibly weaker external environment and a liquidity squeeze for banks dependent on wholesale funding. Over the longer term, a persistent deterioration of cost competitiveness may ultimately pose a constraint to sustaining the growth momentum. Exporters of low-tech and low-skill products and the tourism sector remain particularly vulnerable to rising labor costs and growing competition. Furthermore, constraints to employment and productivity growth remain on account of labor and product market rigidities, as well as infrastructure deficiencies. Tackling these challenges will require wage moderation, further investment in product upgrading, and persevering with and broadening the efforts to reform the product and labor markets. Pursuing a gradualist reform agenda is likely to increase underlying vulnerabilities and the need for deeper adjustments later. 
Stimulating an informed public debate to build social and political consensus in favor of more ambitious and early reforms is essential.

28. The banking system appears to be sound and has been largely unaffected by the global financial turmoil, but key risks will need to be monitored closely. Continued rapid credit growth and the increasing presence in southeastern Europe, financed in part through wholesale funding, has increased Greek banks' exposure to credit, country, and liquidity risks. Stress testing should be upgraded to take into account correlation of risks. Steps taken to strengthen supervision and foster cooperation with SEE supervisory authorities are appropriate and timely. In the insurance sector, the adoption of a risk-based approach to supervision by the new supervisor is welcome.

29. Fiscal consolidation should be sustained over the medium term in view of the current high level of public debt and the prospective large aging related costs. The authorities' aim of achieving a balanced budget by 2010 is appropriate, but further adjustment thereafter to a surplus position is necessary. The revenue target of the 2008 budget is ambitious, and the authorities will need to undertake considerable efforts to achieve it and remain within the overall deficit target. Achieving budget balance by 2010 will require further revenue enhancing measures and determined efforts to control spending.

30. A primary focus of the fiscal consolidation strategy is on improving revenue collections. The emphasis of tax reform in 2008 is on tackling tax evasion through administrative measures, incentives and restructuring of a few taxes. However, improving tax compliance will require further strengthening of tax administration. Consideration should also be given to phasing out distortionary exemptions for all major taxes and simplifying the rate structure.

31. Important reforms to expenditure management have been initiated, and need to be pursued further. Public entities are being made subject to greater transparency and accountability in their operations, and the health care system is being restructured to increase efficiency. Further reform should seek to extend the coverage of the budget, put in place an appropriate financial management information system, and fully integrate program-based budgeting into budget preparation and execution. The introduction of a medium-term budget framework would also help to guide fiscal strategy and prioritize policy objectives.

\section{The authorities are rightly giving priority to pension reform to ensure long-term} fiscal sustainability, though greater ambition is needed. The reform agenda is narrowly focused and the policy proposals are lacking a full assessment of the financing needs and cost savings. The authorities should prepare and publish detailed and realistic projections of the cost of population aging in accordance with EU methodologies, providing the needed basis for a comprehensive reform of the pension system. 


\section{Broader product and labor market reforms are key to regaining lost} competitiveness, increasing the employment rate, and promoting robust productivity growth in a context of domestic economic stability. Important initiatives have been taken recently to simplify the licensing processes and operations of enterprises and to provide economic incentives to encourage investment. The authorities should reinforce their efforts to simplify licensing processes further, privatize infrastructure facilities, and enhance competition in the network industries and the transport sector. The Greek labor market remains relatively rigid by international comparison. Reform should focus on enhancing the flexibility of the wage setting system and easing the restrictiveness of employment protection legislation.

34. It is recommended that the next Article IV consultation take place on the normal 12-month cycle. 
Table 1. Greece: Selected Economic Indicators, 2001-08

\begin{tabular}{|c|c|c|c|c|c|c|c|c|}
\hline & 2001 & 2002 & 2003 & 2004 & 2005 & 2006 & 2007 & 2008 \\
\hline & & & & & & & Staff Est. & Staff Proj. \\
\hline Domestic economy & \multicolumn{8}{|c|}{ (Percentage change, unless otherwise indicated) } \\
\hline Real GDP & 4.5 & 3.9 & 5.0 & 4.6 & 3.8 & 4.2 & 4.0 & 3.7 \\
\hline Output gap & 0.4 & 0.5 & 1.5 & 2.4 & 2.3 & 2.5 & 2.5 & 2.2 \\
\hline Total domestic demand & 2.6 & 5.1 & 6.6 & 4.9 & 3.0 & 5.4 & 4.9 & 4.4 \\
\hline Private consumption & 4.5 & 4.2 & 5.0 & 4.7 & 4.2 & 4.2 & 3.2 & 3.3 \\
\hline Public consumption & 0.4 & 7.3 & -1.0 & 2.7 & 1.4 & -0.7 & 4.2 & 0.7 \\
\hline Gross fixed capital formation & 4.1 & 10.7 & 15.4 & 6.0 & 0.7 & 14.8 & 8.9 & 9.0 \\
\hline Change in stocks (contribution) & -1.3 & -0.9 & 0.5 & 0.3 & 0.1 & -0.4 & 0.1 & 0.0 \\
\hline Foreign balance (contribution) $1 /$ & 1.5 & -1.7 & -2.4 & -1.1 & 0.4 & -2.0 & -1.7 & -1.3 \\
\hline Exports of goods and services & -2.7 & -7.7 & 2.5 & 12.6 & 2.7 & 5.1 & 7.6 & 6.6 \\
\hline Imports of goods and services & -5.8 & -0.2 & 8.7 & 10.7 & 0.5 & 8.7 & 9.1 & 7.2 \\
\hline Unemployment rate (percent) $2 /$ & 10.4 & 9.9 & 9.4 & 10.2 & 9.5 & 8.6 & 7.8 & 7.0 \\
\hline Employment 2/ & 0.2 & 2.0 & 1.9 & 0.9 & 1.5 & 2.5 & 1.7 & 1.8 \\
\hline Unit labor costs (economy wide) & 2.9 & 3.2 & 1.4 & 4.9 & 3.7 & 3.3 & 3.8 & 3.4 \\
\hline Consumer prices (HICP), period average & 3.7 & 3.9 & 3.4 & 3.0 & 3.5 & 3.3 & 3.0 & 3.3 \\
\hline Core prices, period average $3 /$ & 3.5 & 3.6 & 3.0 & 3.2 & 3.3 & 2.4 & 3.1 & $\ldots$ \\
\hline GDP deflator & 2.7 & 3.7 & 3.5 & 3.4 & 3.3 & 3.4 & 3.1 & 3.3 \\
\hline Balance of payments & \multicolumn{8}{|c|}{ (Percent of GDP, settlements basis) } \\
\hline Current account & -7.2 & -6.5 & -6.4 & -5.8 & -7.4 & -11.0 & -13.8 & -13.9 \\
\hline Trade balance & -8.5 & -7.6 & -6.5 & -5.4 & -6.1 & -9.3 & -10.7 & -11.3 \\
\hline Export of goods and services & 23.0 & 20.0 & 19.0 & 21.3 & 20.9 & 20.8 & 21.2 & 22.0 \\
\hline Export of goods & 7.9 & 6.6 & 6.5 & 6.8 & 7.2 & 7.5 & 7.6 & 7.9 \\
\hline Exports of services & 15.1 & 13.4 & 12.5 & 14.4 & 13.8 & 13.3 & 13.6 & 14.2 \\
\hline Imports of goods and services & 31.5 & 27.6 & 25.5 & 26.7 & 27.0 & 30.1 & 31.9 & 33.3 \\
\hline Imports of goods & 22.7 & 21.0 & 19.7 & 20.6 & 21.0 & 24.0 & 25.5 & 26.8 \\
\hline Imports of services & 8.8 & 6.6 & 5.8 & 6.1 & 6.0 & 6.1 & 6.4 & 6.5 \\
\hline Public finances (general government) & \multicolumn{8}{|c|}{ (Percent of GDP) } \\
\hline Total revenues & 40.9 & 40.0 & 39.3 & 38.2 & 38.0 & 39.5 & 39.9 & 41.0 \\
\hline Total expenditures & 45.4 & 44.7 & 44.9 & 45.5 & 43.0 & 42.0 & 42.6 & 42.6 \\
\hline Overall balance & -4.5 & -4.7 & -5.6 & -7.3 & -5.1 & -2.5 & -2.7 & -1.6 \\
\hline Primary balance & 2.0 & 0.7 & -0.7 & -2.4 & -0.7 & 1.6 & 1.2 & 2.4 \\
\hline Structural overall balance (percent of potential output) & -4.7 & -5.0 & -6.3 & -8.4 & -6.1 & -3.6 & -3.8 & -2.6 \\
\hline Gross debt & 104 & 101 & 98 & 99 & 98 & 95 & 93 & 91 \\
\hline \multicolumn{9}{|l|}{ Interest rates and credit } \\
\hline Long-term lending interest rate & 8.6 & 7.4 & 5.9 & 5.8 & 5.8 & 6.3 & 7.21 & $\ldots$ \\
\hline Private credit growth $4 / 5 /$ & 24.8 & 16.9 & 17.0 & 19.5 & 21.8 & 20.6 & 21.4 & $\ldots$ \\
\hline \multicolumn{9}{|l|}{ Exchange rates } \\
\hline Nominal effective exchange rate & 3.0 & 3.6 & 5.4 & 0.9 & -2.7 & 1.8 & 2.3 & $\ldots$ \\
\hline Real effective exchange rate (CPI-based) & 3.0 & 4.3 & 6.1 & 1.3 & -1.5 & 2.3 & 2.6 & $\ldots$ \\
\hline Real effective exchange rate (manufacturing ULC-based' & 0.3 & 5.0 & 13.3 & 9.0 & -2.5 & 5.7 & 5.6 & $\ldots$ \\
\hline \multicolumn{9}{|l|}{ Memorandum item: } \\
\hline Nominal GDP (billions of euros) & 146 & 158 & 171 & 185 & 199 & 214 & 230 & 246 \\
\hline
\end{tabular}

Sources: National Statistical Service; Ministry of Economy and Finance; Bank of Greece; and IMF staff estimates.

$1 /$ ESA95 basis. This is not comparable to bank settlements basis data (see Box 2).

2/ ESA95 basis.

3/ Core prices exclude energy, food, alcohol, and tobacco.

4/ As of November, 2007.

5/ Domestic credit growth of households and enterprises. 
Table 2. Greece: Macroeconomic Framework, 2001-10

\begin{tabular}{|c|c|c|c|c|c|c|c|c|c|c|}
\hline & 2001 & 2002 & 2003 & 2004 & 2005 & 2006 & 2007 & 2008 & 2009 & 2010 \\
\hline & & & & & & & Estimate & \multicolumn{3}{|c|}{ Projection } \\
\hline & \multicolumn{10}{|c|}{ (Percent of nominal GDP, unless otherwise indicated) } \\
\hline Gross national saving & 11.4 & 10.3 & 11.2 & 11.4 & 10.4 & 11.3 & 12.3 & 13.2 & 14.3 & 15.2 \\
\hline Private & 11.6 & 11.0 & 12.8 & 14.0 & 12.6 & 12.4 & 13.4 & 13.0 & 13.3 & 13.8 \\
\hline Household & 1.2 & 0.8 & 1.1 & 1.1 & 0.5 & 0.9 & 1.3 & 1.2 & 1.2 & 1.2 \\
\hline Corporate & 10.3 & 10.2 & 11.7 & 12.9 & 12.0 & 11.6 & 12.1 & 11.8 & 12.1 & 12.5 \\
\hline Public & -0.1 & -0.7 & -1.6 & -2.5 & -2.2 & -1.1 & -1.2 & 0.3 & 1.0 & 1.5 \\
\hline Investment & 21.9 & 22.0 & 24.4 & 24.7 & 23.8 & 25.7 & 26.8 & 28.2 & 29.0 & 29.9 \\
\hline Private & 18.3 & 18.6 & 20.7 & 21.0 & 20.8 & 22.6 & 23.7 & 25.1 & 25.9 & 26.9 \\
\hline Household & 10.9 & 11.3 & 12.4 & 12.5 & 12.4 & 13.6 & 14.7 & 15.0 & 15.2 & 15.5 \\
\hline Corporate & 7.4 & 7.4 & 8.3 & 8.5 & 8.4 & 9.0 & 9.0 & 10.1 & 10.7 & 11.4 \\
\hline Public & 3.6 & 3.3 & 3.6 & 3.7 & 3.0 & 3.1 & 3.1 & 3.1 & 3.1 & 3.0 \\
\hline Foreign saving & -10.5 & -11.6 & -13.2 & -13.3 & -13.4 & -14.4 & -14.6 & -15.0 & -14.8 & -14.7 \\
\hline Saving-investment balance & -10.5 & -11.6 & -13.2 & -13.3 & -13.4 & -14.4 & -14.5 & -15.0 & -14.7 & -14.7 \\
\hline Private & -6.8 & -7.6 & -7.9 & -7.0 & -8.2 & -10.2 & -10.2 & -12.2 & -12.7 & -13.1 \\
\hline Household & -9.7 & -10.4 & -11.3 & -11.4 & -11.8 & -12.7 & -13.4 & -13.8 & -14.0 & -14.3 \\
\hline Corporate & 2.9 & 2.8 & 3.4 & 4.4 & 3.7 & 2.5 & 3.1 & 1.7 & 1.3 & 1.2 \\
\hline Public & -3.7 & -4.0 & -5.2 & -6.3 & -5.2 & -4.2 & -4.3 & -2.8 & -2.1 & -1.5 \\
\hline Memorandum items: & \multicolumn{10}{|c|}{ (Percentage change, in real terms, unless otherwise indicated) } \\
\hline General government balance (percent of GDP) & -4.5 & -4.7 & -5.6 & -7.3 & -5.1 & -2.5 & -2.7 & -1.6 & -0.9 & -0.3 \\
\hline Real GDP & 4.5 & 3.9 & 5.0 & 4.6 & 3.8 & 4.2 & 4.0 & 3.7 & 3.5 & 3.6 \\
\hline Final domestic demand & 3.8 & 5.9 & 6.1 & 4.7 & 3.0 & 5.8 & 4.8 & 4.4 & 3.9 & 4.1 \\
\hline Private consumption & 4.5 & 4.2 & 5.0 & 4.7 & 4.2 & 4.2 & 3.2 & 3.3 & 3.1 & 3.2 \\
\hline Gross fixed capital formation & 4.1 & 10.7 & 15.4 & 6.0 & 0.7 & 14.8 & 8.9 & 9.0 & 7.3 & 7.5 \\
\hline
\end{tabular}

Sources: National Statistical Service of Greece; Ministry of Economy and Finance; and IMF staff calculations. 
Table 3. Greece: Medium-Term Baseline Scenario, 2004-13

\begin{tabular}{|c|c|c|c|c|c|c|c|c|c|c|}
\hline & 2004 & 2005 & 2006 & 2007 & 2008 & 2009 & 2010 & 2011 & 2012 & 2013 \\
\hline & & & & Estimate & \multicolumn{6}{|c|}{ Projection } \\
\hline Domestic economy & \multicolumn{10}{|c|}{ (Percentage change) } \\
\hline Real GDP & 4.6 & 3.8 & 4.2 & 4.0 & 3.7 & 3.5 & 3.6 & 3.5 & 3.5 & 3.5 \\
\hline Output gap & 2.4 & 2.3 & 2.5 & 2.5 & 2.2 & 1.8 & 1.4 & 0.9 & 0.4 & 0.0 \\
\hline Total domestic demand & 4.9 & 3.0 & 5.4 & 4.9 & 4.4 & 3.9 & 4.1 & 3.9 & 3.9 & 3.9 \\
\hline Private consumption & 4.7 & 4.2 & 4.2 & 3.2 & 3.3 & 3.1 & 3.2 & 3.0 & 3.0 & 3.0 \\
\hline Public consumption & 2.7 & 1.4 & -0.7 & 4.2 & 0.7 & 1.0 & 1.2 & 1.2 & 1.2 & 1.2 \\
\hline Gross fixed capital formation & 6.0 & 0.7 & 14.8 & 8.9 & 9.0 & 7.3 & 7.5 & 7.0 & 7.0 & 7.0 \\
\hline Foreign balance (contribution) $1 /$ & -1.1 & 0.4 & -2.0 & -1.7 & -1.3 & -1.1 & -1.2 & -1.1 & -1.1 & -1.2 \\
\hline Exports of goods and services & 12.6 & 2.7 & 5.1 & 7.6 & 6.6 & 6.6 & 6.5 & 6.5 & 6.5 & 6.5 \\
\hline Imports of goods and services & 10.7 & 0.5 & 8.7 & 9.1 & 7.2 & 6.4 & 6.6 & 6.3 & 6.4 & 6.4 \\
\hline Unemployment rate (percent) 2/ & 10.2 & 9.5 & 8.6 & 7.8 & 7.0 & 6.7 & 6.4 & 6.2 & 6.4 & 6.7 \\
\hline Employment 2/ & 0.9 & 1.5 & 2.5 & 1.7 & 1.8 & 1.5 & 1.5 & 1.2 & 0.8 & 0.7 \\
\hline Unit labor costs (economy wide) & 4.9 & 3.7 & 3.3 & 3.8 & 3.4 & 3.0 & 2.9 & 2.6 & 2.4 & 2.4 \\
\hline Consumer prices (HICP), end of period & 3.1 & 3.5 & 3.2 & 3.9 & 2.6 & 2.7 & 2.6 & 2.5 & 2.5 & 2.5 \\
\hline Consumer prices (HICP), period average & 3.0 & 3.5 & 3.3 & 3.0 & 3.3 & 2.7 & 2.6 & 2.5 & 2.5 & 2.5 \\
\hline GDP deflator & 3.4 & 3.3 & 3.4 & 3.1 & 3.3 & 2.9 & 2.7 & 2.6 & 2.6 & 2.6 \\
\hline External sector & \multicolumn{10}{|c|}{ (Percent of GDP) } \\
\hline Current account & -5.8 & -7.4 & -11.0 & -13.8 & -13.9 & -14.1 & -13.9 & -12.9 & -12.6 & -12.7 \\
\hline Trade balance & -5.4 & -6.1 & -9.3 & -10.7 & -11.3 & -11.4 & -11.0 & -9.9 & -9.5 & -9.5 \\
\hline Exports of goods and services & 21.3 & 20.9 & 20.8 & 21.2 & 22.0 & 22.2 & 22.2 & 21.9 & 21.9 & 22.1 \\
\hline Imports of goods and services & 26.7 & 27.0 & 30.1 & 31.9 & 33.3 & 33.5 & 33.2 & 31.9 & 31.4 & 31.6 \\
\hline Current transfers & 2.0 & 1.6 & 1.6 & 0.7 & 1.4 & 1.5 & 1.5 & 1.6 & 1.6 & 1.6 \\
\hline Net income receipts & -2.4 & -2.9 & -3.3 & -3.9 & -4.0 & -4.2 & -4.4 & -4.6 & -4.7 & -4.8 \\
\hline \multicolumn{11}{|l|}{ Public finances (general government) } \\
\hline Total revenues & 38.2 & 38.0 & 39.5 & 39.9 & 41.0 & 41.7 & 42.3 & 42.1 & 42.1 & 42.2 \\
\hline Total expenditures & 45.5 & 43.0 & 42.0 & 42.6 & 42.6 & 42.5 & 42.6 & 42.3 & 42.1 & 42.0 \\
\hline Primary expenditures & 40.5 & 38.6 & 37.9 & 38.6 & 38.7 & 38.6 & 38.8 & 38.6 & 38.6 & 38.7 \\
\hline Interest expenditures & 5.0 & 4.4 & 4.1 & 3.9 & 4.0 & 3.9 & 3.8 & 3.7 & 3.5 & 3.3 \\
\hline Overall balance & -7.3 & -5.1 & -2.5 & -2.7 & -1.6 & -0.9 & -0.3 & -0.1 & 0.0 & 0.2 \\
\hline Primary balance & -2.4 & -0.7 & 1.6 & 1.2 & 2.4 & 3.0 & 3.5 & 3.5 & 3.5 & 3.5 \\
\hline Structural overall balance (percent of potential output) & -8.4 & -6.1 & -3.6 & -3.8 & -2.6 & -1.6 & -0.9 & -0.5 & -0.1 & 0.2 \\
\hline Structural primary balance (percent of potential output) & -3.3 & -1.6 & 0.7 & 0.3 & 1.5 & 2.3 & 2.9 & 3.2 & 3.4 & 3.5 \\
\hline Gross debt & 99 & 98 & 95 & 93 & 91 & 88 & 84 & 80 & 76 & 72 \\
\hline \multicolumn{11}{|l|}{ Memorandum item: } \\
\hline Nominal GDP (billions of euros) & 185 & 199 & 214 & 230 & 246 & 262 & 279 & 296 & 315 & 334 \\
\hline
\end{tabular}

Sources: National Statistical Service; Ministry of Economy and Finance; Bank of Greece; and IMF staff estimates.

$1 /$ ESA95 basis. This is not comparable to bank settlements basis data (see Box 2).

2/ ESA95 basis. 
Table 4. Greece: Summary of Balance of Payments, 2004-13 1/

\begin{tabular}{|c|c|c|c|c|c|c|c|c|c|c|}
\hline & 2004 & 2005 & 2006 & 2007 & 2008 & 2009 & 2010 & 2011 & 2012 & 2013 \\
\hline & & & & Estimate & \multicolumn{6}{|c|}{ Projection } \\
\hline & \multicolumn{10}{|c|}{ (Billions of euros) } \\
\hline Current account balance & -10.7 & -14.6 & -23.6 & -31.8 & -34.1 & -36.9 & -38.7 & -38.2 & -39.6 & -42.3 \\
\hline Balance of goods and services & -10.0 & -12.1 & -19.9 & -24.5 & -27.7 & -29.7 & -30.7 & -29.5 & -29.9 & -31.6 \\
\hline Goods balance & -25.4 & -27.6 & -35.3 & -41.1 & -46.6 & -50.0 & -52.5 & -52.9 & -55.1 & -58.7 \\
\hline Exports of goods & 12.7 & 14.2 & 16.2 & 17.4 & 19.3 & 20.6 & 21.5 & 21.5 & 22.2 & 23.5 \\
\hline Imports of goods & 38.1 & 41.8 & 51.4 & 58.5 & 65.9 & 70.6 & 73.9 & 74.4 & 77.3 & 82.3 \\
\hline Services balance & 15.5 & 15.5 & 15.4 & 16.6 & 18.9 & 20.3 & 21.8 & 23.4 & 25.2 & 27.1 \\
\hline Credit & 26.7 & 27.4 & 28.4 & 31.3 & 34.9 & 37.5 & 40.3 & 43.4 & 46.8 & 50.3 \\
\hline Debit & 11.3 & 11.9 & 13.0 & 14.6 & 16.0 & 17.2 & 18.6 & 20.0 & 21.5 & 23.2 \\
\hline Income balance & -4.4 & -5.7 & -7.1 & -9.0 & -9.9 & -11.0 & -12.2 & -13.5 & -14.7 & -16.0 \\
\hline Credit & 2.8 & 3.3 & 3.6 & 4.9 & 5.3 & 5.7 & 6.1 & 6.6 & 7.1 & 7.5 \\
\hline Debit & 7.2 & 8.9 & 10.7 & 13.9 & 15.2 & 16.8 & 18.4 & 20.1 & 21.8 & 23.5 \\
\hline Current transfers (net) & 3.6 & 3.1 & 3.4 & 1.7 & 3.5 & 3.8 & 4.2 & 4.7 & 5.0 & 5.3 \\
\hline Capital and financial account balance & 10.1 & 14.7 & 23.4 & 31.8 & 34.1 & 36.9 & 38.7 & 38.2 & 39.6 & 42.3 \\
\hline Capital account balance & 2.4 & 2.0 & 3.0 & 3.3 & 3.5 & 3.7 & 4.0 & 4.2 & 4.5 & 4.7 \\
\hline Financial account & 7.8 & 12.6 & 20.4 & 28.5 & 30.6 & 33.2 & 34.8 & 34.0 & 35.1 & 37.5 \\
\hline Direct investment & 0.9 & -0.7 & 1.0 & 0.4 & 0.2 & 0.5 & 0.4 & 0.4 & 0.4 & 0.4 \\
\hline Portfolio investment & 13.7 & 7.3 & 8.1 & 9.7 & 8.4 & 8.7 & 8.9 & 8.7 & 8.8 & 8.8 \\
\hline Financial derivatives & -0.3 & 0.0 & 0.0 & -0.1 & 0.0 & 0.0 & -0.1 & 0.0 & 0.0 & 0.0 \\
\hline Other investment & -9.1 & 5.9 & 11.5 & 18.5 & 22.0 & 24.0 & 25.5 & 25.0 & 25.9 & 28.4 \\
\hline Reserve assets & 2.6 & 0.0 & -0.2 & 0.0 & 0.0 & 0.0 & 0.0 & 0.0 & 0.0 & 0.0 \\
\hline \multirow[t]{2}{*}{ Net errors and omissions } & -0.6 & 0.1 & -0.2 & 0.0 & 0.0 & 0.0 & 0.0 & 0.0 & 0.0 & 0.0 \\
\hline & \multicolumn{10}{|c|}{ (Percent of GDP) } \\
\hline \multicolumn{11}{|l|}{ Memorandum items: } \\
\hline Current account balance & -5.8 & -7.4 & -11.0 & -13.8 & -13.9 & -14.1 & -13.9 & -12.9 & -12.6 & -12.7 \\
\hline Balance of goods and services & -5.4 & -6.1 & -9.3 & -10.7 & -11.3 & -11.4 & -11.0 & -9.9 & -9.5 & -9.5 \\
\hline Goods balance & -13.7 & -13.9 & -16.5 & -17.9 & -18.9 & -19.1 & -18.8 & -17.9 & -17.5 & -17.6 \\
\hline Services balance & 8.4 & 7.8 & 7.2 & 7.3 & 7.7 & 7.8 & 7.8 & 7.9 & 8.0 & 8.1 \\
\hline Income balance & -2.4 & -2.9 & -3.3 & -3.9 & -4.0 & -4.2 & -4.4 & -4.6 & -4.7 & -4.8 \\
\hline Current transfers & 2.0 & 1.6 & 1.6 & 0.7 & 1.4 & 1.5 & 1.5 & 1.6 & 1.6 & 1.6 \\
\hline $\begin{array}{l}\text { Capital and financial account balance } \\
\text { Of which: }\end{array}$ & 5.5 & 7.4 & 10.9 & 13.8 & 13.9 & 14.1 & 13.9 & 12.9 & 12.6 & 12.7 \\
\hline Direct investment & 0.5 & -0.3 & 0.4 & 0.2 & 0.1 & 0.2 & 0.1 & 0.1 & 0.1 & 0.1 \\
\hline Portfolio investment & 7.4 & 3.7 & 3.8 & 4.2 & 3.4 & 3.3 & 3.2 & 2.9 & 2.8 & 2.6 \\
\hline Other investment & -4.9 & 3.0 & 5.4 & 8.1 & 9.0 & 9.2 & 9.1 & 8.4 & 8.2 & 8.5 \\
\hline External debt & 100.4 & 112.2 & 117.0 & 120.3 & 123.9 & 128.0 & 131.8 & 134.7 & 137.1 & 139.6 \\
\hline Public sector & 70.8 & 76.8 & 76.1 & $\ldots$ & $\ldots$ & $\ldots$ & $\ldots$ & $\ldots$ & $\ldots$ & $\ldots$ \\
\hline Private sector & 29.5 & 35.5 & 40.9 & $\ldots$ & $\ldots$ & $\ldots$ & $\ldots$ & $\ldots$ & $\ldots$ & $\ldots$ \\
\hline
\end{tabular}

Sources: Bank of Greece; and IMF staff projections.

1/ Bank settlements basis. 
Table 5. Greece: Core Set of Financial Soundness Indicators for Deposit Taking Institutions, 2000-07 (Percent)

\begin{tabular}{|c|c|c|c|c|c|c|c|c|}
\hline & 2000 & 2001 & 2002 & 2003 & 2004 & 2005 & 2006 & Q3 2007 \\
\hline Regulatory capital to risk-weighted assets $1 /$ & 13.6 & 12.4 & 10.5 & 12.0 & 12.8 & 13.2 & 12.2 & 11.4 \\
\hline Regulatory Tier I capital to risk-weighted assets $1 /$ & 13.5 & 10.9 & 8.8 & 9.8 & 10.0 & 10.9 & 9.9 & 9.2 \\
\hline Nonperforming loans net of provisions to capital 2/ & 33.4 & 29.4 & 28.9 & 27.0 & 26.5 & 19.2 & 15.4 & 17.1 \\
\hline Nonperforming loans to total gross loans $2 /$ & 11.7 & 8.3 & 7.4 & 7.0 & 7.0 & 6.3 & 5.4 & 5.1 \\
\hline \multicolumn{9}{|l|}{ Sectoral distribution of loans $3 /$} \\
\hline Consumer credit & 9.3 & 10.6 & 11.3 & 12.3 & 14.3 & 15.2 & 16.3 & 16.5 \\
\hline Lending for house purchase & 18.8 & 21.0 & 24.4 & 26.1 & 27.7 & 31.4 & 33.4 & 33.5 \\
\hline Non-financial corporations & 70.5 & 65.7 & 60.4 & 57.7 & 54.4 & 50.5 & 47.1 & 46.7 \\
\hline Insurance corporations and pension funds & 0.1 & 0.1 & 0.1 & 0.1 & 0.1 & 0.1 & 0.1 & 0.1 \\
\hline Other financial intermediaries & 1.1 & 2.2 & 3.2 & 2.6 & 2.3 & 1.6 & 1.8 & 1.5 \\
\hline Other & 0.3 & 0.4 & 0.6 & 1.3 & 1.2 & 1.2 & 1.4 & 1.7 \\
\hline Return on assets (after taxes) 2/ 4/ & 1.4 & 1.0 & 0.5 & 0.6 & 0.4 & 0.9 & 0.8 & 1.3 \\
\hline Return on equity (after taxes) $2 / 4 /$ & 15.4 & 12.4 & 6.8 & 8.9 & 6.4 & 15.9 & 12.8 & 20.1 \\
\hline Interest margin to gross income 2/ 4/ & 54.5 & 62.8 & 72.5 & 73.9 & 77.0 & 75.5 & 72.5 & 68.7 \\
\hline Non-interest expenses to gross income 2/ 4/ & 53.0 & 59.0 & 69.0 & 63.0 & 64.3 & 54.5 & 52.2 & 47.8 \\
\hline Liquid assets to total assets $3 /$ & 46.4 & 41.1 & 39.5 & 37.0 & 33.4 & 34.0 & 33.6 & 33.0 \\
\hline Liquid assets to short-term liabilities $3 /$ & 60.7 & 53.0 & 48.7 & 46.5 & 43.2 & 47.0 & 46.5 & 46.2 \\
\hline Net open position in foreign exchange to capital $1 / 2 / 5 /$ & $\ldots$ & 3.5 & 7.2 & 5.7 & 3.5 & 2.8 & 4.8 & 5.8 \\
\hline
\end{tabular}

Source: Bank of Greece.

$1 /$ Data on a consolidated basis.

2/ 2007 figures refer to end-June, 2007.

3/ On an aggregate resident-based approach (i.e. commercial banks, cooperative banks and foreign branches).

4/ From 2004 in accordance with IFRS.

5/ Based on revised figures from 2002 onwards. 
Table 6. Greece: Encouraged Set of Financial Soundness Indicators, 2000-07

(Percent)

\begin{tabular}{|c|c|c|c|c|c|c|c|c|}
\hline & 2000 & 2001 & 2002 & 2003 & 2004 & 2005 & 2006 & Q3 2007 \\
\hline \multicolumn{9}{|l|}{ Corporate Sector } \\
\hline Total debt to equity & $\ldots$ & 127.1 & 139.0 & 150.1 & 147.9 & 157.3 & 173.9 & 180.0 \\
\hline Return on equity $1 /$ & $\ldots$ & 5.8 & 5.1 & 5.8 & 7.1 & 5.9 & 8.6 & $\ldots$ \\
\hline Earnings to interest expenses $2 /$ & $\ldots$ & 6.0 & 6.1 & 5.9 & 5.2 & 2.2 & 2.0 & \\
\hline Number of applications for protection from creditors & 1756 & 1838 & 1156 & 2052 & 1635 & 1958 & 2281 & 1524 \\
\hline \multicolumn{9}{|l|}{ Deposit-taking institutions } \\
\hline Capital to assets $3 / 4 /$ & 9.2 & 8.5 & 6.9 & 6.9 & 5.3 & 5.9 & 6.7 & 6.2 \\
\hline \multicolumn{9}{|l|}{$\begin{array}{l}\text { Geographical distribution of loans to total loans (enterprises and } \\
\text { households) } 5 /\end{array}$} \\
\hline Domestic & 93.9 & 94.7 & 95.6 & 96.3 & 96.6 & 96.8 & 97.1 & 96.2 \\
\hline Other euro area countries & 0.2 & 0.2 & 0.2 & 0.1 & 0.2 & 0.1 & 0.1 & 0.1 \\
\hline Non-euro area countries & 5.9 & 5.1 & 4.2 & 3.5 & 3.2 & 3.1 & 2.9 & 3.7 \\
\hline Large exposures to capital $3 /$ & $\ldots$ & & 154.1 & 190.8 & 123.7 & 144.5 & 127.0 & 143.6 \\
\hline Trading income to total income $3 / 4$ / & 17.3 & 13.1 & 4.9 & 4.6 & 3.0 & 3.8 & 8.4 & 8.5 \\
\hline Personnel expenses to noninterest expenses $3 / 4 /$ & 61.8 & 59.8 & 59.0 & 58.2 & 61.6 & 59.9 & 59.3 & 61.5 \\
\hline Spread between reference lending and deposit rates (end of period) 6/ & 6.4 & 6.1 & 6.1 & 5.8 & 5.9 & 6.0 & 6.1 & 6.3 \\
\hline Customer deposits to total (non-interbank) loans $5 /$ & 176.3 & 166.0 & 147.4 & 135.3 & 130.6 & 127.5 & 126.3 & 124.2 \\
\hline Foreign currency-denominated liabilities to total liabilities $5 /$ & 24.5 & 16.6 & 12.8 & 13.2 & 12.9 & 12.7 & 13.1 & 13.5 \\
\hline Net open position in equities in capital 3/ 7/ & $\ldots$ & 21.5 & 12.9 & 10.4 & 5.8 & 3.1 & 4.7 & 3.8 \\
\hline \multicolumn{9}{|l|}{ Market liquidity } \\
\hline Average bid-ask spread in the securities market & 14.0 & 9.8 & 9.4 & 8.2 & 6.1 & 7.9 & 7.4 & 11.9 \\
\hline Average daily turnover ratio in the securities market $8 /$ & 0.1 & 0.2 & 0.2 & 0.1 & 0.2 & 0.1 & 0.1 & 0.2 \\
\hline \multicolumn{9}{|l|}{ Other financial corporations } \\
\hline Assets to total financial system assets & 17.3 & 16.5 & 15.4 & 16.2 & 16.3 & 13.7 & 12.4 & 10.4 \\
\hline Assets to GDP & 37.6 & 32.3 & 27.4 & 29.2 & 28.7 & 27.4 & 26.1 & 22.8 \\
\hline \multicolumn{9}{|l|}{ Households } \\
\hline Household debt to GDP & 12.5 & 16.3 & 20.6 & 24.4 & 29.6 & 35.6 & 41.2 & 47.4 \\
\hline \multicolumn{9}{|l|}{ Real estate markets } \\
\hline Residential real estate loans to total loans $5 /$ & 10.2 & 13.2 & 16.7 & 18.2 & 20.7 & 22.9 & 24.8 & 23.9 \\
\hline
\end{tabular}

Sources: Bank of Greece; and ICAP, Greek Financial Directory, 2008.

1/ For 2005 and 2006, source is ICAP, Greek Financial Directory, 2008.

2/ Principal expenses not available.

3/ 2007 figures refer to end-June, 2007.

4/ On a non-consolidated basis; from 2004 in accordance with IFRS.

5/ On an aggregate resident-based approach (i.e. commercial banks, cooperative banks, and foreign branches).

6 / Spread between rate on credit lines and savings deposit rate.

7/ Data on a consolidated basis.

8 / Figures refer to volumes of securities traded and not numbers. 
Table 7. Greece: Structure of Financial System, 2000-07

\begin{tabular}{|c|c|c|c|c|c|c|c|c|}
\hline & 2000 & 2001 & 2002 & 2003 & 2004 & 2005 & 2006 & Q3 2007 \\
\hline & \multicolumn{8}{|c|}{ (Number) } \\
\hline Banks & 19 & 23 & 24 & 22 & 21 & 21 & 21 & 19 \\
\hline Private commercial & 8 & 12 & 12 & 12 & 13 & 13 & 8 & 8 \\
\hline State-owned & 7 & 7 & 7 & 6 & 3 & 3 & 3 & 3 \\
\hline Foreign-owned subsidiaries & 4 & 4 & 5 & 4 & 5 & 5 & 10 & 8 \\
\hline Branches of foreign banks & 22 & 21 & 21 & 20 & 23 & 23 & 24 & 25 \\
\hline Securities companies & 90 & 88 & 103 & 98 & 75 & 65 & 60 & 67 \\
\hline General insurance companies $1 /$ & 90 & 89 & 89 & 92 & 89 & 86 & 81 & 81 \\
\hline Other credit institutions & 16 & 17 & 17 & 17 & 18 & 18 & 17 & 17 \\
\hline \multicolumn{9}{|l|}{ Concentration 2/ } \\
\hline Banks & 7 & 7 & 7 & 7 & 7 & 7 & 8 & 7 \\
\hline General insurance companies & $\ldots$ & $\ldots$ & 10 & 10 & 11 & 11 & 11 & 12 \\
\hline Assets & \multicolumn{8}{|c|}{ (billions of euros) } \\
\hline Banks & 145.7 & 158.7 & 165.5 & 174.0 & 186.6 & 228.6 & 272.6 & 307.4 \\
\hline Private commercial & 43.2 & 44.8 & 46.7 & 52.4 & 115.6 & 134.7 & 148.7 & 164.2 \\
\hline State-owned & 84.4 & 92.6 & 92.1 & 91.5 & 40.7 & 44.2 & 37.9 & 38.9 \\
\hline Foreign-owned subsidiaries & 18.1 & 21.3 & 26.8 & 30.1 & 30.4 & 49.7 & 85.9 & 104.2 \\
\hline Branches of foreign banks & 22.3 & 17.8 & 17.4 & 19.2 & 23.0 & 28.5 & 31.8 & 35.5 \\
\hline General insurance companies & 13.2 & 12.4 & 9.1 & 10.2 & 10.9 & 15.5 & 17.5 & 17.9 \\
\hline Other credit institutions & 13.6 & 15.2 & 16.6 & 17.7 & 20.7 & 24.3 & 10.8 & 11.3 \\
\hline \multicolumn{9}{|l|}{ Deposits } \\
\hline Banks & 89.9 & 98.6 & 102.9 & 112.4 & 125.8 & 151.3 & 183.1 & 207.7 \\
\hline Private commercial & 23.6 & 25.9 & 26.9 & 30.8 & 69.5 & 86.9 & 95.1 & 105.3 \\
\hline State-owned & 55.9 & 59.0 & 59.9 & 63.2 & 31.3 & 34.0 & 31.1 & 32.9 \\
\hline Foreign-owned subsidiaries & 10.3 & 13.6 & 16.1 & 18.4 & 25.0 & 30.4 & 57.0 & 69.6 \\
\hline Branches of foreign banks & 8.5 & 8.9 & 8.9 & 9.5 & 12.7 & 16.9 & 19.5 & 20.8 \\
\hline
\end{tabular}

Source: Bank of Greece.

1/ There are no specialised life insurance companies in Greece. General insurance companies offer general insurance and life insurance products.

2/ Number of institutions (in each category) with 75 percent of total assets. 


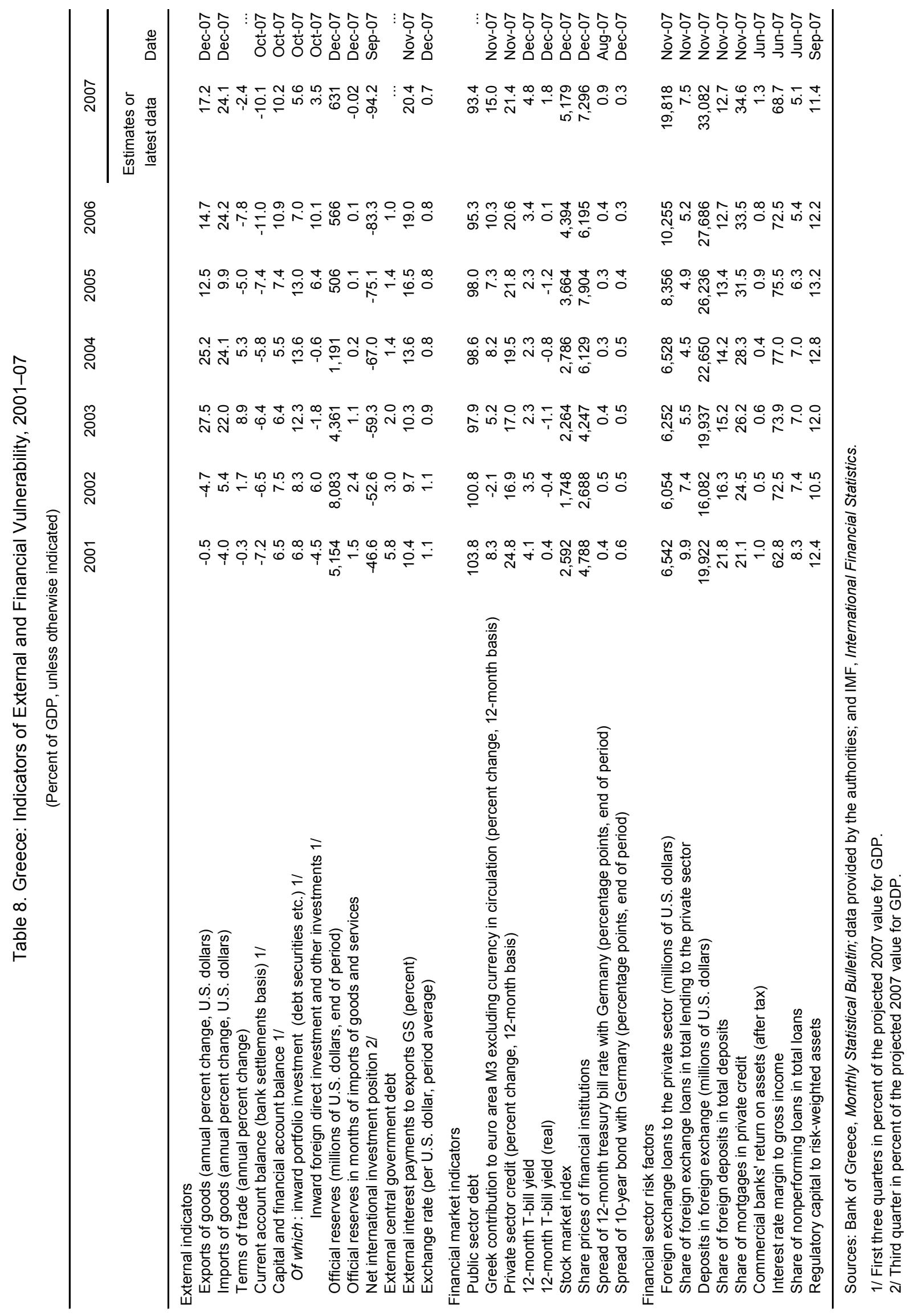


Table 9. Greece: General Government Accounts, 2001-08

\begin{tabular}{|c|c|c|c|c|c|c|c|c|}
\hline & 2001 & 2002 & 2003 & 2004 & 2005 & 2006 & 2007 & 2008 \\
\hline & & & & & & & Estimate & Budget \\
\hline & \multicolumn{7}{|c|}{ (Billions of Euros) } & \\
\hline Revenues & 59.8 & 63.0 & 67.3 & 70.7 & 75.4 & 84.6 & 91.5 & 100.8 \\
\hline Taxes on production and imports & 19.4 & 20.2 & 20.8 & 21.6 & 22.8 & 25.6 & 28.3 & 32.3 \\
\hline Taxes on income and property & 12.5 & 13.4 & 13.5 & 14.8 & 16.6 & 17.0 & 18.1 & 20.2 \\
\hline Social insurance contributions & 18.4 & 21.3 & 23.7 & 24.7 & 26.1 & 28.3 & 30.6 & 33.1 \\
\hline Other & 7.3 & 6.2 & 6.4 & 6.5 & 6.8 & 7.9 & 8.3 & 9.7 \\
\hline Capital transfers & 2.1 & 1.9 & 2.9 & 3.1 & 3.1 & 5.9 & 6.2 & 5.4 \\
\hline Expenditures & 66.4 & 70.5 & 76.9 & 84.2 & 85.5 & 89.9 & 97.7 & 104.8 \\
\hline Intermediate consumption & 9.1 & 10.2 & 10.1 & 9.8 & 9.8 & 9.9 & 10.8 & 10.5 \\
\hline Remuneration of workers & 15.2 & 17.3 & 18.5 & 21.2 & 22.4 & 23.1 & 24.7 & 26.9 \\
\hline Social transfers, excl. those in kind & 22.5 & 24.2 & 27.3 & 28.9 & 31.8 & 35.5 & 39.4 & 43.6 \\
\hline Interest & 9.5 & 8.6 & 8.5 & 9.2 & 8.8 & 8.9 & 9.0 & 9.7 \\
\hline Investment expenditure & 8.5 & 8.4 & 9.9 & 11.7 & 9.1 & 9.4 & 10.3 & 10.6 \\
\hline Of which: Olympics related expenditures & 0.2 & 1.2 & 1.7 & 2.7 & 0.6 & 0.0 & 0.0 & 0.0 \\
\hline \multirow[t]{2}{*}{ Overall balance } & -6.5 & -7.5 & -9.6 & -13.6 & -10.1 & -5.4 & -6.2 & -4.0 \\
\hline & \multicolumn{6}{|c|}{ (Percent of GDP) } & & \\
\hline Revenues & 40.9 & 40.0 & 39.3 & 38.2 & 38.0 & 39.5 & 39.9 & 41.1 \\
\hline Taxes on production and imports & 13.3 & 12.8 & 12.1 & 11.7 & 11.5 & 11.9 & 12.3 & 13.2 \\
\hline Taxes on income and property & 8.6 & 8.5 & 7.9 & 8.0 & 8.4 & 7.9 & 7.9 & 8.2 \\
\hline Social insurance contributions & 12.6 & 13.5 & 13.9 & 13.3 & 13.1 & 13.2 & 13.3 & 13.5 \\
\hline Other & 5.0 & 4.0 & 3.7 & 3.5 & 3.4 & 3.7 & 3.6 & 4.0 \\
\hline Capital transfers & 1.5 & 1.2 & 1.7 & 1.7 & 1.5 & 2.8 & 2.7 & 2.2 \\
\hline Expenditures & 45.4 & 44.7 & 44.9 & 45.5 & 43.0 & 42.0 & 42.6 & 42.7 \\
\hline Intermediate consumption & 6.2 & 6.5 & 5.9 & 5.3 & 4.9 & 4.6 & 4.7 & 4.3 \\
\hline Remuneration of workers & 10.4 & 11.0 & 10.8 & 11.4 & 11.3 & 10.8 & 10.8 & 11.0 \\
\hline Social transfers, excl. those in kind & 15.4 & 15.3 & 16.0 & 15.6 & 16.0 & 16.6 & 17.2 & 17.8 \\
\hline Interest & 6.5 & 5.5 & 4.9 & 5.0 & 4.4 & 4.1 & 3.9 & 4.0 \\
\hline Of which: Olympics related expenditures & 0.2 & 0.8 & 1.0 & 1.5 & 0.3 & 0.0 & 0.0 & 0.0 \\
\hline Overall balance & -4.5 & -4.7 & -5.6 & -7.3 & -5.1 & -2.5 & -2.7 & -1.6 \\
\hline \multicolumn{9}{|l|}{ Memorandum items: } \\
\hline Primary expenditures (billions of euros) & 56.9 & 61.9 & 68.4 & 75.0 & 76.7 & 81.1 & 88.7 & 95.1 \\
\hline Primary balance (billions of euros) & 3.0 & 1.2 & -1.1 & -4.4 & -1.3 & 3.5 & 2.8 & 5.7 \\
\hline Primary expenditures & 38.9 & 39.3 & 40.0 & 40.5 & 38.6 & 37.9 & 38.6 & 38.7 \\
\hline Primary balance & 2.0 & 0.7 & -0.7 & -2.4 & -0.7 & 1.6 & 1.2 & 2.3 \\
\hline Structural primary balance (percent of potential output) & 1.9 & 0.5 & -1.3 & -3.3 & -1.6 & 0.7 & 0.3 & 1.5 \\
\hline Structural overall balance (percent of potential output) & -4.7 & -5.0 & -6.3 & -8.4 & -6.1 & -3.6 & -3.8 & -2.6 \\
\hline Gross debt & 104 & 101 & 98 & 99 & 98 & 95 & 93 & 91 \\
\hline Nominal GDP (billions of euros) & 146 & 158 & 171 & 185 & 199 & 214 & 230 & 245 \\
\hline
\end{tabular}

Sources: Ministry of Economy and Finance; and IMF staff calculations. 
Table 10. Greece: Doing Business Indicators, 2008

\begin{tabular}{lrr}
\hline & Greece & EU-15 average \\
& & $\begin{array}{c}\text { (excl. Greece and } \\
\text { Luxembourg) }\end{array}$ \\
\hline Starting a business & 15 & 6 \\
Number of procedures & 38 & 15 \\
Time (days) & 23 & 5 \\
Cost (percent of income per capita) & & 14 \\
Licenses and permits & 15 & 169 \\
Number of procedures & 169 & 65 \\
Time (days) & 62 & 1 \\
Cost (percent of income per capita) & & \\
Closing a business & 2 & 28 \\
Time (years) & 9 & 45 \\
Cost (percent of estate) & & 34 \\
Labor indices 1/ & 44 & 36 \\
Difficulty of hiring index & 80 & 30 \\
Rigidity of hours index & 40 & \\
Difficulty of firing index & 55 & 22 \\
Rigidity of employment index & 24 & 40 \\
Firing costs (weeks of wages) & & 44 \\
Rankings 2/ & 100 & 88 \\
Ease of doing business & 152 & 42 \\
Starting a business & 38 & \\
Licenses and permits & 142 & \\
Closing a business & & \\
Labor & & \\
\hline
\end{tabular}

Source: World Bank, Doing Business, 2008.

$1 /$ Unless otherwise indicated, the figures are indices which range from 0 to 100 , with higher numbers indicating greater rigidity.

2/ Ranking out of 178. 
Figure 1. Greece: Selected Indicators, 2000-08
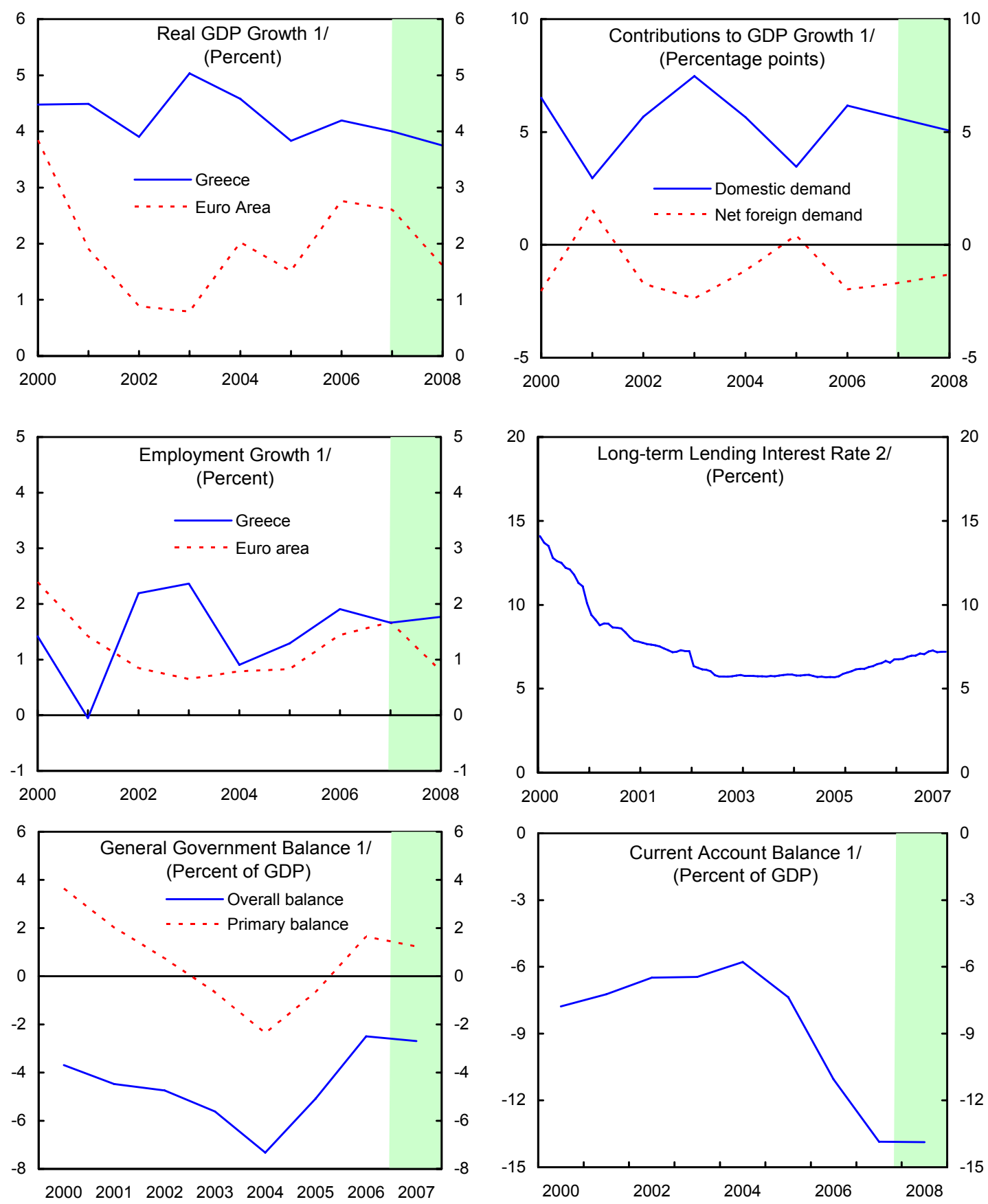

Sources: IMF, International Financial Statistics; IMF, World Economic Outlook; National Statistical Service of Greece; Bank of Greece, Bulletin of Conjunctural Indicators; and Bloomberg.

$1 /$ Projection for 2008.

2/ Data for 2007 as of December. 
Figure 2. Greece and the euro area: HICP Inflation, 2001-08
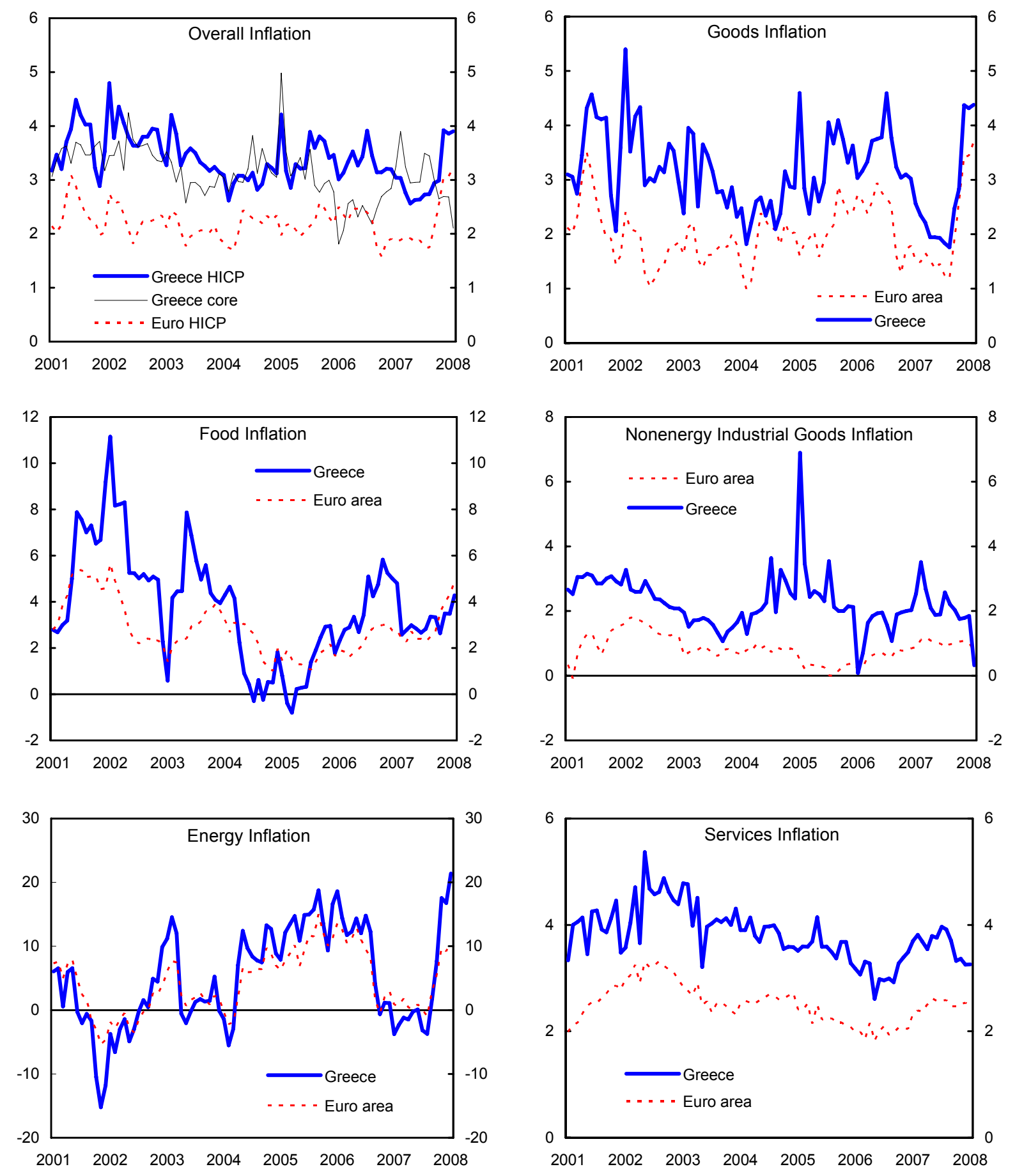

Source: Eurostat. 
Figure 3. Greece: Public Debt Sustainability: Bound Tests 1/

(Public debt in percent of GDP)
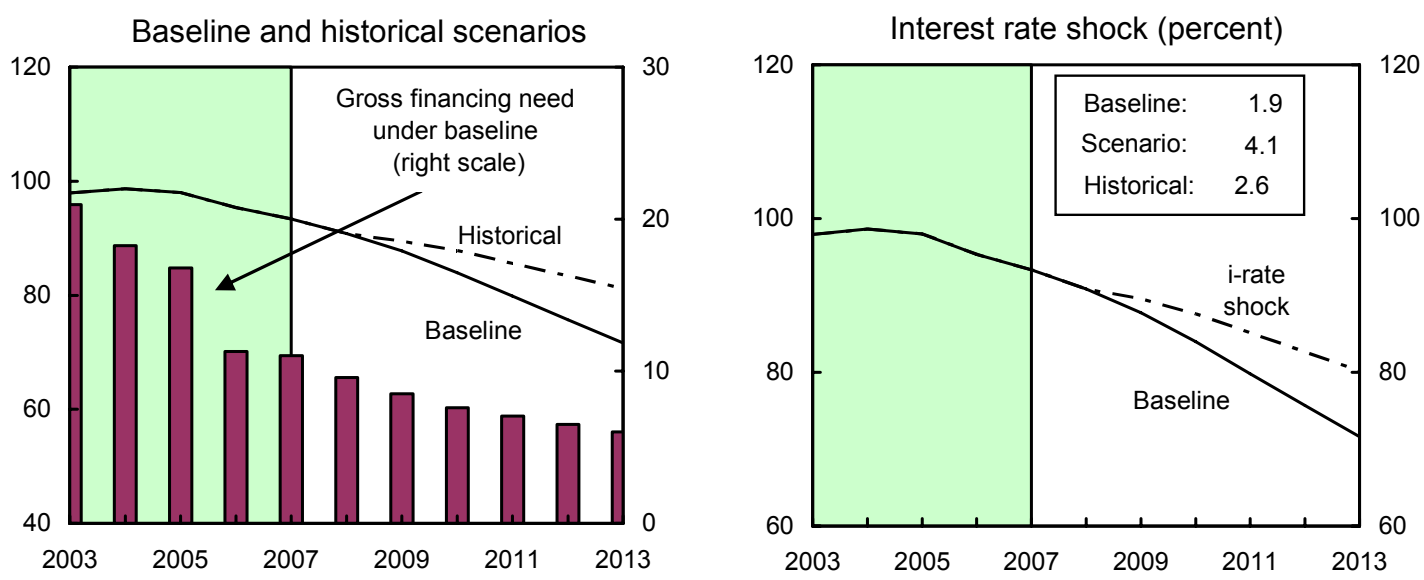

Growth shock (percent per year)

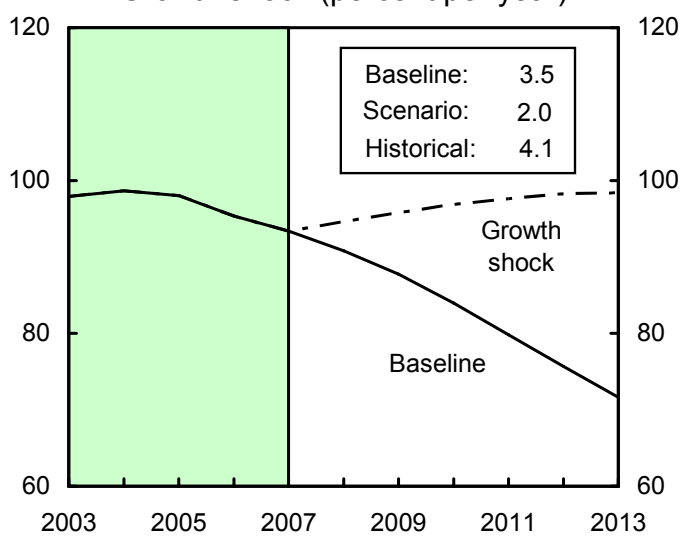

Primary balance shock (percent of GDP) and no policy change scenario (constant primary balance)

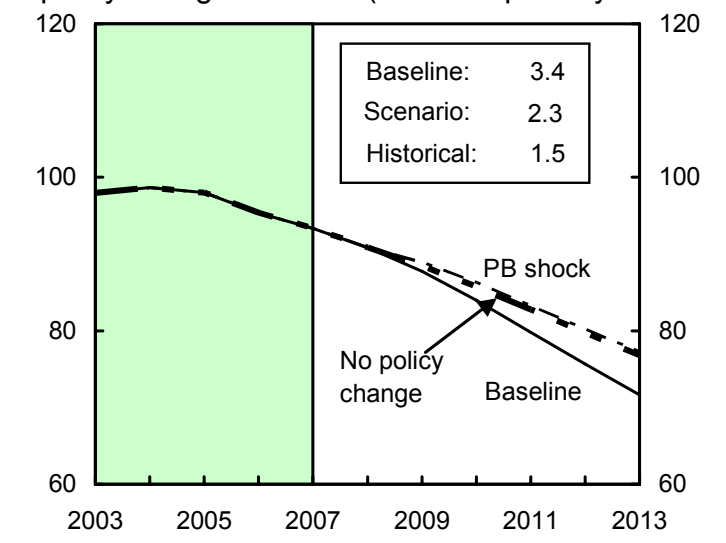

Combined shock 2/

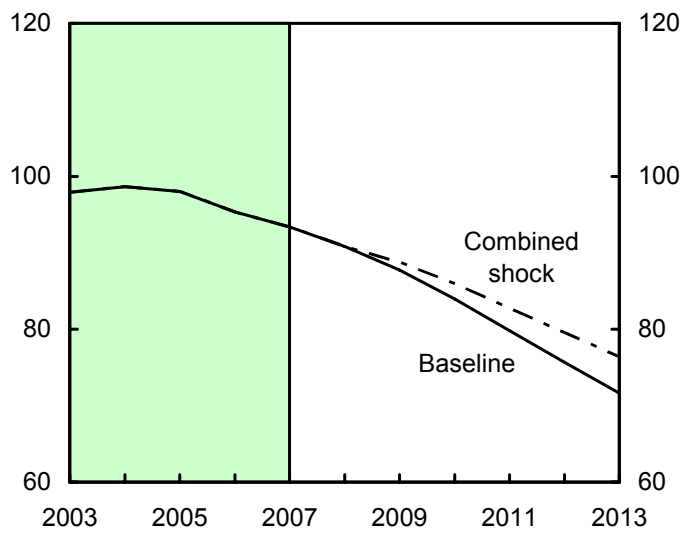

Real depreciation and contingent liabilities shocks $3 /$

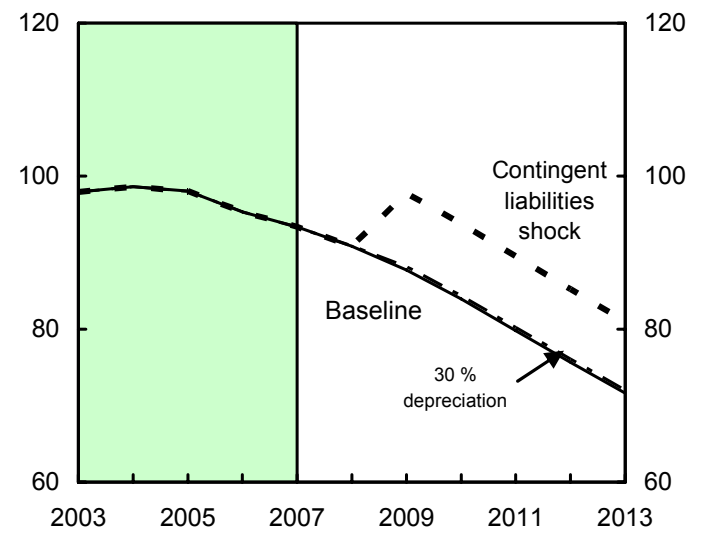

Sources: International Monetary Fund; country desk data; and IMF staff estimates.

1/ Shaded areas represent actual data. Individual shocks are permanent one-half standard deviation shocks except for the interest rate and growth shocks. The growth shock assumes that real GDP growth drops to 0.8 percent in 2008 and it recovers gradually to 3.1 percent by 2013. Figures in the boxes represent average projections for the respective variables in the baseline and scenario being presented. Ten-year historical average for the variable is also shown.

2/ Permanent 1/4 standard deviation shocks applied to real interest rate, growth rate, and primary balance.

$3 /$ One-time real depreciation of 30 percent and 10 percent of GDP shock to contingent liabilities occur in 2009, with real depreciation defined as nominal depreciation (measured by percentage fall in dollar value of local currency) minus domestic inflation (based on GDP deflator). 
Figure 4. Greece: Credit Developments, 2000-07

(Percent)
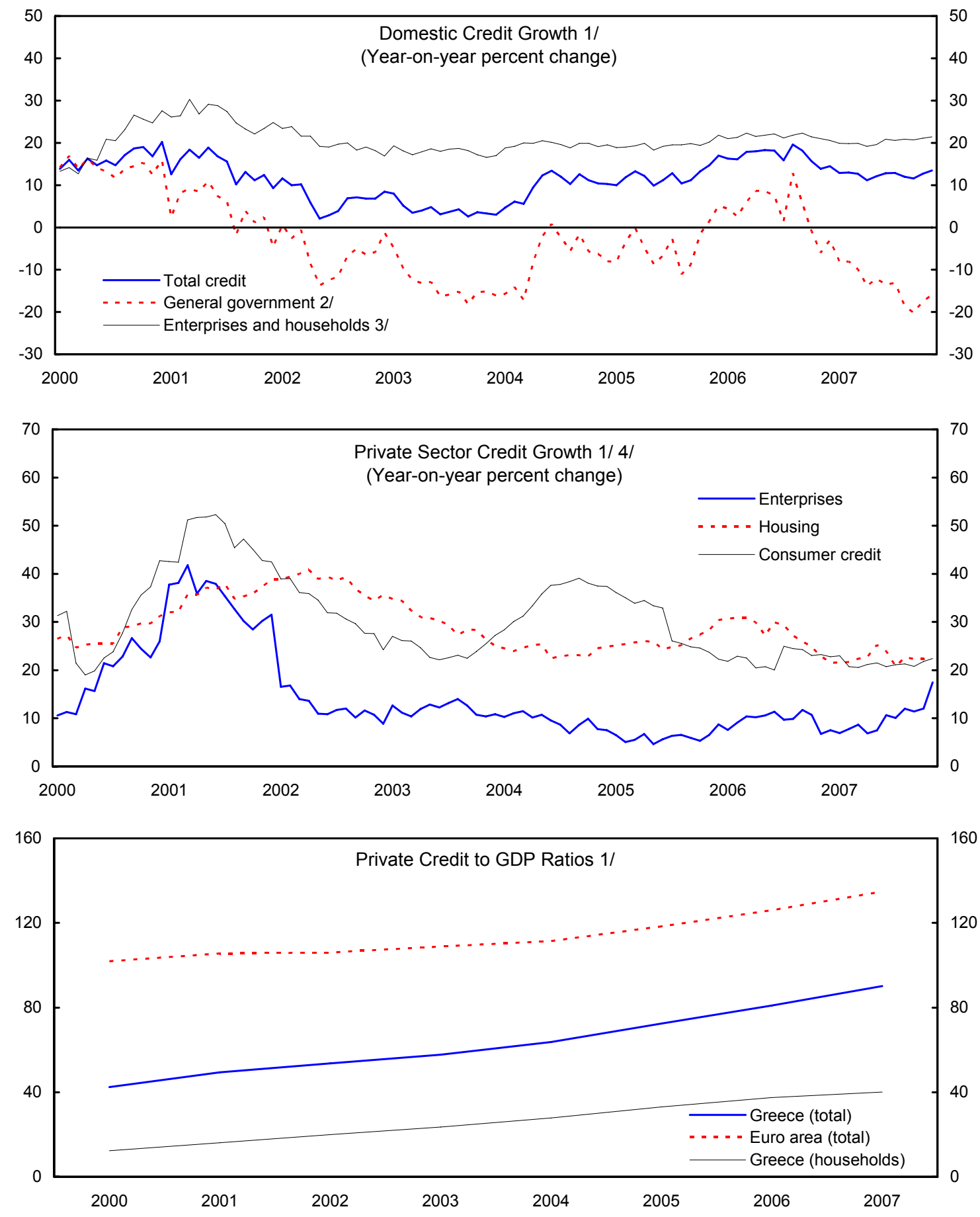

Sources: IMF, International Financial Statistics; National Statistical Service of Greece; and Bank of Greece, Bulletin of Conjunctural Indicators.

1/ Data for 2007 as of November.

2/ Data prior to 1999 refer to public sector.

3/ Data prior to 1999 refer to private sector.

4/ Data prior to 2000 refers to commercial bank credit. 
Figure 5. Greece: Labor Market Indicators, 2006
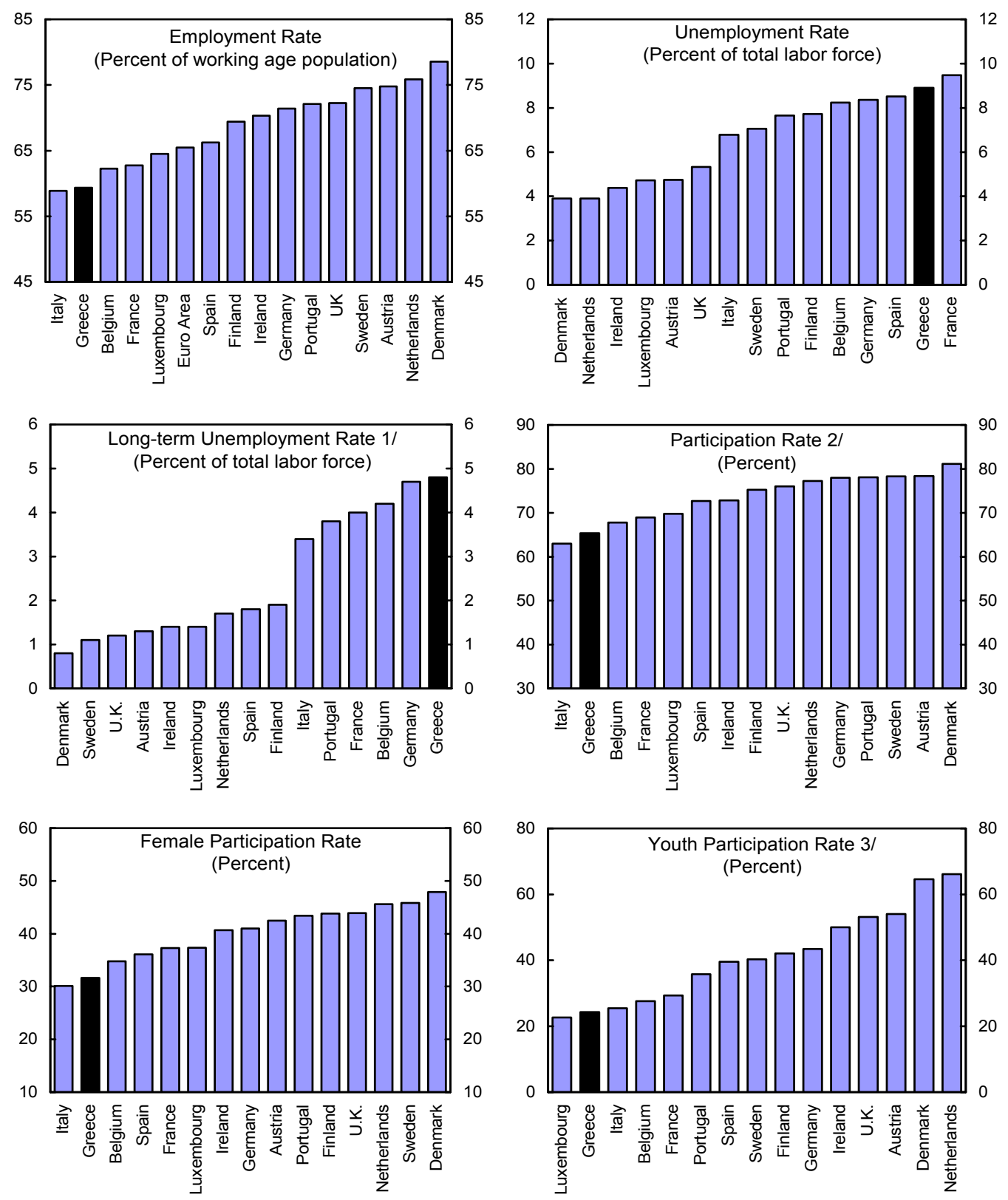

Sources: Eurostat; IMF, World Economic Outlook; and OECD, Economic Outlook.

$1 /$ Unemployed for 12 months or more.

2/ Labor force divided by the labor force population.

$3 /$ Youths are between 15 and 24 years of age. 
Figure 6. Greece: Labor Market Restrictions
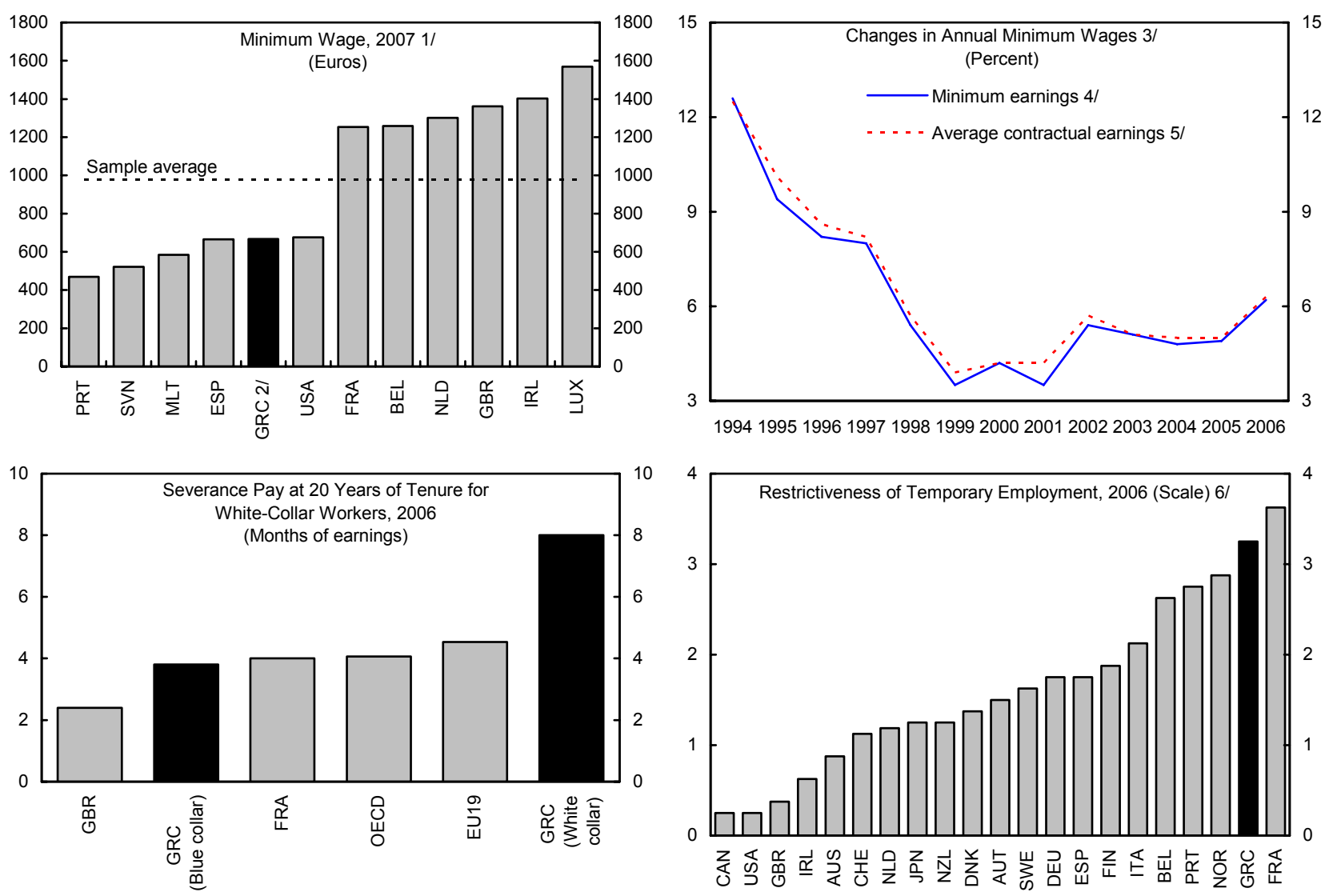

Sources: OECD, Employment Outlook; and Bank of Greece.

$1 /$ Monthly minimum wage for January.

2/ Data as of July, 2006.

$3 /$ Non-bank sector.

4/ National general collective labor agreement.

$5 /$ Calculations based on data from collective labor agreements at branch and occupational levels.

6/ From 0 to 6 , with 6 the most restrictive. 
Figure 7. Greece: Product Markets Restrictiveness Indicators

(Scale)
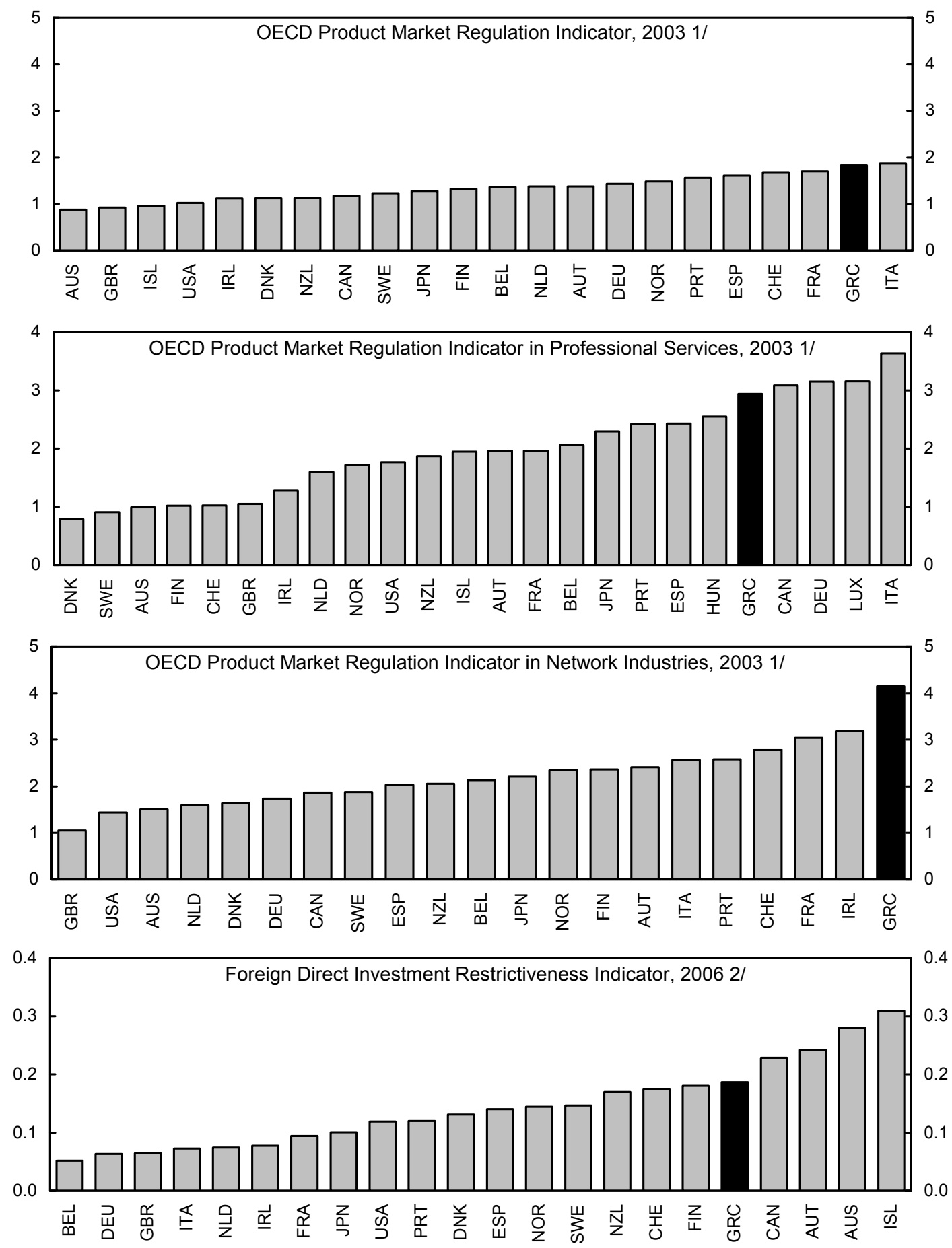

Sources: OECD, Indicators of Product Market Regulation; and Koyama and Golub, OECD's FDI Regulatory Restrictiveness Index: Revision and Extension to more Economies (2006).

$1 /$ From 0 to 6 , with 6 the most restrictive.

2/ From 0 to 1, with 1 the most restrictive. 


\section{APPENDiX I. GREECE: FUND RELATIONS}

(As of January 31, 2008)

- Mission: November 29-December 10, 2007 and January 22-25, 2008 in Athens. The
concluding statement of the mission is available at
http://www.imf.org/external/np/ms/2007/121007a.htm
- Staff team: Mr. Banerjee (Head), Ms. Honjo and Ms. Moreno Badia (all EUR), and
Mr. Chua (FAD).
Country interlocutors: Ministry of Economy and Finance, Bank of Greece, other
government ministries and agencies, trade unions, industrialists, and banks.
Fund relations: Greece has accepted the obligations of Article VIII, Sections 2,3 ,
and 4 and maintains an exchange system free of restrictions apart from those resulting
from European Council regulations, which were last notified to the Fund in
accordance with Decision 144 under EBD/07/5, 1/17/07. Greece subscribes to SDDS,
and has undertaken an FSAP and fiscal and data ROSCs.
Outreach: The mission met with trade unions and industrialists.

I. Membership Status: Joined December 27, 1945; Article VIII

$\begin{array}{lcc}\text { II. General Resources Account: } & \text { SDR Million } & \text { \% Quota } \\ \text { Quota } & 823.00 & 100.00 \\ \text { Fund holdings of currency } & 768.98 & 93.44 \\ \text { Reserve position in Fund } & 54.03 & 6.57\end{array}$

III. SDR Department:

Net cumulative allocation Holdings

\section{SDR Million}

103.54

17.42
$\%$ Allocation

100.00

16.83

IV. Outstanding Purchases and Loans: None

V. Financial Arrangements: None 
VI. Projected Obligations to Fund (SDR million; based on existing use of resources and present holdings of SDRs):

\begin{tabular}{lccccc}
\hline & \multicolumn{5}{c}{ Forthcoming } \\
\cline { 2 - 6 } & 2008 & 2009 & 2010 & 2011 & 2012 \\
\hline Principal & & & & & \\
Charges/Interest & 2.76 & 2.66 & 2.67 & 2.67 & 2.67 \\
Total & 2.76 & 2.66 & 2.67 & 2.67 & 2.67 \\
\hline
\end{tabular}

VII. Implementation of HIPC Initiative: Not Applicable.

\section{Exchange Rate Arrangements:}

Greece's currency is the euro, which floats freely and independently against other currencies. Greece entered the final stage of European Economic and Monetary Union on January 1, 2001, at a rate of 340.750 Greek drachmas per 1 euro. Greece maintains restrictions on the making of payments for current international transactions vis-à-vis Iraq. These restrictions were last notified to the Fund in accordance with Decision 144 under $\mathrm{EBD} / 07 / 5,1 / 17 / 07$.

IX. Article IV Consultation: Greece is on a 12-month consultation cycle; the last Article IV consultation discussions were concluded on January 22, 2007.

\section{ROSCs}

\section{Standard Code Assessment}

Fiscal Transparency

Fiscal Transparency

Fiscal Transparency

Fiscal Transparency

Data Module

Data Module Update

Fiscal Transparency

Anti-Money Laundering and

Combating the Financing of

Terrorism

Banking Supervision

Insurance Supervision

Securities Regulation

Data Module Update

Fiscal Transparency
Date of Issuance

October 6, 1999

February 8, 2001

February 4, 2002

May 5, 2003

September 17, 2003

December 22, 2004

December 22, 2004

November 22, 2005

November 22, 2005

November 22, 2005

November 22, 2005

November 22, 2005

January 20, 2006

\section{Document Number}

IMF Country Report No. 99/138

IMF Country Report No. 99/138

IMF Country Report No. 99/138

IMF Country Report No.03/158

IMF Country Report No.03/318

IMF Country Report No.05/45

IMF Country Report No.05/42

IMF Country Report No.06/6

IMF Country Report No.06/6

IMF Country Report No.06/6

IMF Country Report No.06/6

IMF Country Report No.06/4

IMF Country Report No.06/49 
XI. Technical Assistance:

Year Dept. Purpose Date

1993 FAD Treasury Reform June

1993 MAE Central Bank Independence in the Context of the June Maastricht Treaty

1994 MAE Development of Primary and Secondary Markets in September Government Securities

2002 STA Action plan and time frame for SDDS subscription June

2003 FAD Tax Policy and Tax Administration Reform July

2005 FAD Public Expenditure Management May

2005 FAD Tax Administration July

2005 FAD Fiscal Transparency July

XII. Resident Representative: None 


\section{APPENDIX II. GREece: STATISTICAL ISSUES}

Economic data are adequate for surveillance, but should be strengthened. Substantial progress has been made in statistical methodologies and practices to fulfill responsibilities as a member of the European Union and the euro area. Greece subscribed to the Special Data Dissemination Standard (SDDS) on November 8, 2002. A data module of the Report on the Observance of Standards and Codes (ROSC) was published in 2003, and it was updated in 2004 and 2005 in the context of the Article IV staff report.

National accounts produced by the National Statistical Service of Greece (NSSG) have recently been revised substantially, in part to comply with the European System of Accounts (ESA95). The new benchmark year is 2000. The revision follows the availability of new statistical sources, in particular the census of population, new structural surveys of construction companies, hotels and restaurants, transportation, as well as an update of the household budget survey.

The seasonal adjustment of quarterly national accounts estimates relies on indicator series rather than standard techniques. The resulting series retain strong seasonal patterns which render them inadequate for assessing short-term economic developments. The NSGG plans to introduce properly seasonally adjusted quarterly national accounts.

Balance of payments data present some departures from the fifth edition of the Balance of Payments Manual (BPM5), but progress has been made implementing the recommendations of the 2003 data ROSC. Significant differences remain in comparison to national accountsbased current account data (see Box).

The NSSG compiles data on general government revenue, expenditure, and deficit on an accrual basis in the context of the 1995 ESA Transmission Program and the Excessive Deficit Procedure. The absence of financing data impedes checks on data consistency, including reconciliation between the government deficit and debt, and between government finance statistics and other macroeconomic datasets.

The interpretation of labor market developments continues to be hampered by difficulties in covering immigrants, which constitute, compared with other EU countries, a relatively large fraction of the labor market, and by the large size of the unrecorded economy, which the recent national accounts revisions may not have fully captured.

Under the Coordinated Compilation Exercise for Financial Soundness Indicators conducted by the Fund, the authorities recently produced a set of indicators broadly consistent with the Fund's FSI Compilation Guide. 


\section{Discrepancies in External Accounts Data}

There is currently a large statistical discrepancy between national accounts and balance of payments data, which cannot be easily reconciled. Based on national accounts, the negative foreign balance has exceeded 10 percent of GDP and steadily risen since 2001. In contrast, balance of payments data show more moderate external imbalances that have widened only recently reflecting higher oil prices and a temporary pick-up in investment in new ships. The discrepancy has been in the range of 3-7 percent of GDP a year during 2000-06.

The large discrepancy reflects differences in data source and methodology for external merchandise trade. National accounts are compiled using customs data which are then adjusted in accordance with ESA 95 to include estimates for triangular merchanting trade, illegal activities, defense, smuggling, and oil transactions in free zones. The balance of payments is compiled on the basis of bank settlements data.

With the reduction in the time lag in availability of customs data, the authorities are planning to shift to this data source to compile the balance of payments.

Discrepancy Between National Accounts and BOP

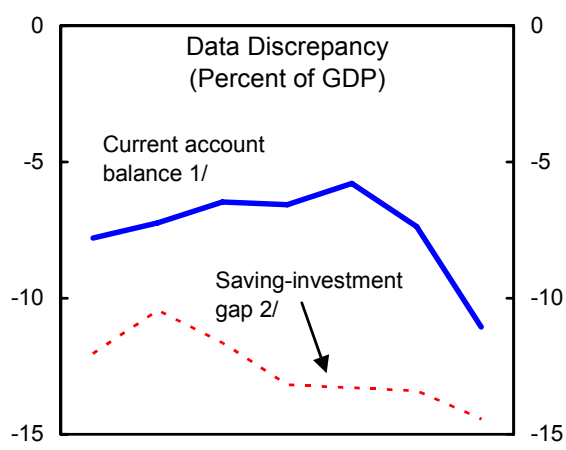

2000200120022003200420052006 Sources: Bank of Greece; National Statistical Service; and IMF staff estimates.

1/ Bank settlements basis.

2/ National accounts basis
(Percentage points of GDP) 1/

\begin{tabular}{|c|c|c|c|c|c|c|}
\hline & \multicolumn{3}{|c|}{ Exports } & \multicolumn{3}{|c|}{ Imports } \\
\hline & Total & Goods & Services & Total & Goods & Services \\
\hline 2000 & 1.3 & 2.3 & -1.0 & 5.1 & 5.0 & 0.1 \\
\hline 2001 & 1.0 & 2.1 & -1.2 & 4.1 & 3.6 & 0.6 \\
\hline 2002 & 1.0 & 2.2 & -1.2 & 5.4 & 4.7 & 0.7 \\
\hline 2003 & 1.3 & 2.3 & -1.0 & 7.5 & 7.3 & 0.2 \\
\hline 2004 & 0.5 & 1.5 & -1.0 & 7.5 & 7.4 & 0.1 \\
\hline 2005 & 0.8 & 1.6 & -0.9 & 6.0 & 6.1 & -0.1 \\
\hline 2006 & 1.1 & 2.0 & -0.9 & 4.3 & 4.3 & 0.0 \\
\hline
\end{tabular}

Sources: Bank of Greece; National Statistical Service; and IMF staff estimates.

1/ National accounts data minus BOP. 


\section{Greece: Table of Common Indicators Required for Surveillance (as of February 29, 2008)}

\begin{tabular}{|c|c|c|c|c|c|c|c|}
\hline & \multirow{2}{*}{$\begin{array}{c}\text { Date of } \\
\text { latest } \\
\text { observation }\end{array}$} & \multirow{2}{*}{$\begin{array}{l}\text { Date } \\
\text { received }\end{array}$} & \multirow{2}{*}{$\begin{array}{c}\text { Frequenc } \\
\text { y of } \\
\text { Data }^{6}\end{array}$} & \multirow{2}{*}{$\begin{array}{l}\text { Frequency } \\
\text { of } \\
\text { Reporting }^{6}\end{array}$} & \multirow{2}{*}{$\begin{array}{l}\text { Frequency } \\
\text { of } \\
\text { Publication }^{6}\end{array}$} & \multicolumn{2}{|c|}{ Memo Items: } \\
\hline & & & & & & $\begin{array}{l}\text { Data Quality - } \\
\text { Methodological } \\
\text { soundness } 7\end{array}$ & $\begin{array}{c}\text { Data Quality } \\
\text { - Accuracy } \\
\text { and } \\
\text { reliability }^{8}\end{array}$ \\
\hline Exchange Rates & 2/29/08 & $2 / 29 / 08$ & $\mathrm{D}$ & $\mathrm{D}$ & $\mathrm{D}$ & & \\
\hline $\begin{array}{l}\text { International Reserve Assets and Reserve } \\
\text { Liabilities of the Monetary Authorities }{ }^{1}\end{array}$ & Jan. 08 & $2 / 26 / 08$ & M & M & M & & \\
\hline Reserve/Base Money & Dec. 07 & $2 / 1 / 08$ & M & M & M & $\mathrm{O}, \mathrm{O}, \mathrm{O}, \mathrm{O}$ & $\mathrm{LO}, \mathrm{O}, \mathrm{O}, \mathrm{O}$ \\
\hline Broad Money & Dec. 07 & $2 / 1 / 08$ & M & M & M & & \\
\hline Central Bank Balance Sheet & Dec. 07 & $2 / 1 / 08$ & M & M & M & & \\
\hline $\begin{array}{l}\text { Consolidated Balance Sheet of the Banking } \\
\text { System }\end{array}$ & Dec. 07 & $2 / 1 / 08$ & M & M & M & & \\
\hline Interest Rates ${ }^{2}$ & $2 / 29 / 08$ & $2 / 29 / 08$ & $\mathrm{D}$ & $\mathrm{D}$ & $\mathrm{D}$ & & \\
\hline Consumer Price Index & Jan. 08 & $2 / 7 / 08$ & $M$ & M & M & $\mathrm{O}, \mathrm{O}, \mathrm{O}, \mathrm{O}$ & $\begin{array}{l}\text { O, LO, O, O, } \\
\text { O }\end{array}$ \\
\hline $\begin{array}{l}\text { Revenue, Expenditure, Balance and } \\
\text { Composition of Financing }{ }^{3}-\text { General } \\
\text { Government }^{4}\end{array}$ & 2006 & $3 / 31 / 07$ & $A$ & $A$ & $A$ & LO, LO, LO, O & $\begin{array}{l}\mathrm{LO}, \mathrm{O}, \mathrm{O}, \mathrm{O}, \\
\mathrm{NA}\end{array}$ \\
\hline $\begin{array}{l}\text { Revenue, Expenditure, Balance and } \\
\text { Composition of Financing }{ }^{3}-\text { Central Government }\end{array}$ & Nov. 07 & $12 / 31 / 07$ & M & M & M & & \\
\hline $\begin{array}{l}\text { Stocks of Central Government and Central } \\
\text { Government-Guaranteed Debt }{ }^{5}\end{array}$ & 2007 Q3 & $11 / 19 / 07$ & Q & Q & Q & & \\
\hline External Current Account Balance & Nov. 07 & $1 / 25 / 08$ & M & M & M & O, LO, LO, O & $\mathrm{O}, \mathrm{O}, \mathrm{O}, \mathrm{O}$ \\
\hline Exports and Imports of Goods and Services & Nov. 07 & $1 / 25 / 08$ & M & M & M & & \\
\hline GDP/GNP & 2007 Q3 & $11 / 14 / 07$ & Q & Q & Q & $\mathrm{O}, \mathrm{O}, \mathrm{O}, \mathrm{O}$ & $\begin{array}{l}\text { LO, LO, O, } \\
\text { O, LO }\end{array}$ \\
\hline Gross External Debt & 2007 Q3 & $12 / 7 / 07$ & Q & Q & Q & & \\
\hline
\end{tabular}

${ }^{1}$ Includes reserve assets pledged or otherwise encumbered as well as net derivative positions.

${ }^{2}$ Both market-based and officially determined, including discount rates, money market rates, rates on treasury bills, notes and bonds.

${ }^{3}$ Foreign, domestic bank, and domestic nonbank financing.

${ }^{4}$ The general government consists of the central government (budgetary funds, extra budgetary funds, and social security funds) and state and local governments.

${ }^{5}$ Including currency and maturity composition.

${ }^{6}$ Daily (D); weekly (W); monthly (M); quarterly (Q); annually (A); irregular (I); and not available (NA).

${ }^{7}$ Reflects the assessment provided in the data ROSC (published in October 2003, and based on the findings of the mission that took place during November 2002) for the dataset corresponding to the variable in each row. The assessment indicates whether international standards concerning concepts and definitions, scope, classification/sectorization, and basis for recording are fully observed (O); largely observed (LO); largely not observed (LNO); not observed (NO); and not available (NA).

${ }^{8}$ Same as footnote 7 , except referring to international standards concerning source data, statistical techniques, assessment and validation of source data, assessment and validation of intermediate data and statistical outputs, and 
INTERNATIONAL MONETARY FUND

\author{
GREECE \\ Staff Report for the 2007 Article IV Consultation \\ Supplementary Information
}

Prepared by the European Department

Approved by Alessandro Leipold and Michael Hadjimichael

April 15, 2008

This supplement contains the authorities' latest estimates for 2007 and updated information on the economic outlook for Greece that have become available since the circulation of the staff report for the Article IV consultation. The key changes are shown in the attached tables. The information does not alter the thrust of the staff appraisal, though stronger projected unit labor cost growth heightens concerns about eroding competitiveness going forward.

\title{
1. Economic growth in $\mathbf{2 0 0 7}$ remains the same as previous estimates but the
} composition of growth has changed. Real GDP growth for 2007 is estimated at 4 percent. Although still the main driver of growth, domestic demand growth is now lower because of weaker investment resulting from a decline in residential construction and lower growth in other investment components. Net external demand has improved relative to previous estimates due to a deceleration of import growth.

2. Both the authorities and staff have revised their forecasts in view of the further deterioration of the global outlook. The authorities now project real GDP growth for 2008-09 at 3.6 percent, 0.4 percentage points lower than previous estimates. The main factors behind this downward adjustment are slower export growth and weaker domestic demand reflecting an expected tightening of credit conditions and the dampening effect of higher inflation on real disposable income and consumption. Staff sees real GDP growth in 2008-09 lower than the authorities, at 3.3 percent, as a result of a less favorable external environment. The staff projections in this supplement are lower than in the World Economic Outlook because of a carry-forward of the lower investment evident in the revised figures for 2007. The current account deficit is, however, projected to improve relative to staff's previous estimates due to lower import growth.

\section{The authorities do not expect the fiscal outturn to be much different from their} baseline scenario. The 2007 general government deficit outturn is now estimated at 2.8 percent of GDP, 0.1 percent of GDP higher than previous estimates. For 2008-10, the authorities' envisaged deficit adjustment path has remained broadly unchanged, with 
however a slightly different composition of revenue and expenditure. Staff projects the general government deficit for 2008-10 to be higher than officially targeted by 0.1-0.4 percent of GDP mainly because of lower economic growth.

\section{Inflation has continued to accelerate in recent months and the inflation outlook} in 2008 is more negative than previously forecast. Inflation was 4.4 percent in March on a year-on-year basis partly boosted by higher food prices. Given the rising inflationary pressures during the first months of 2008 and higher food and oil prices, staff have revised up their inflation forecast for 2008 from 3.3 percent to 3.7 percent. Inflation in 2009 is expected to decline as carryover effects wane. Unit labor cost growth is expected to pick up in 2008 to 5.5 percent and, although declining, remain high in 2009. 


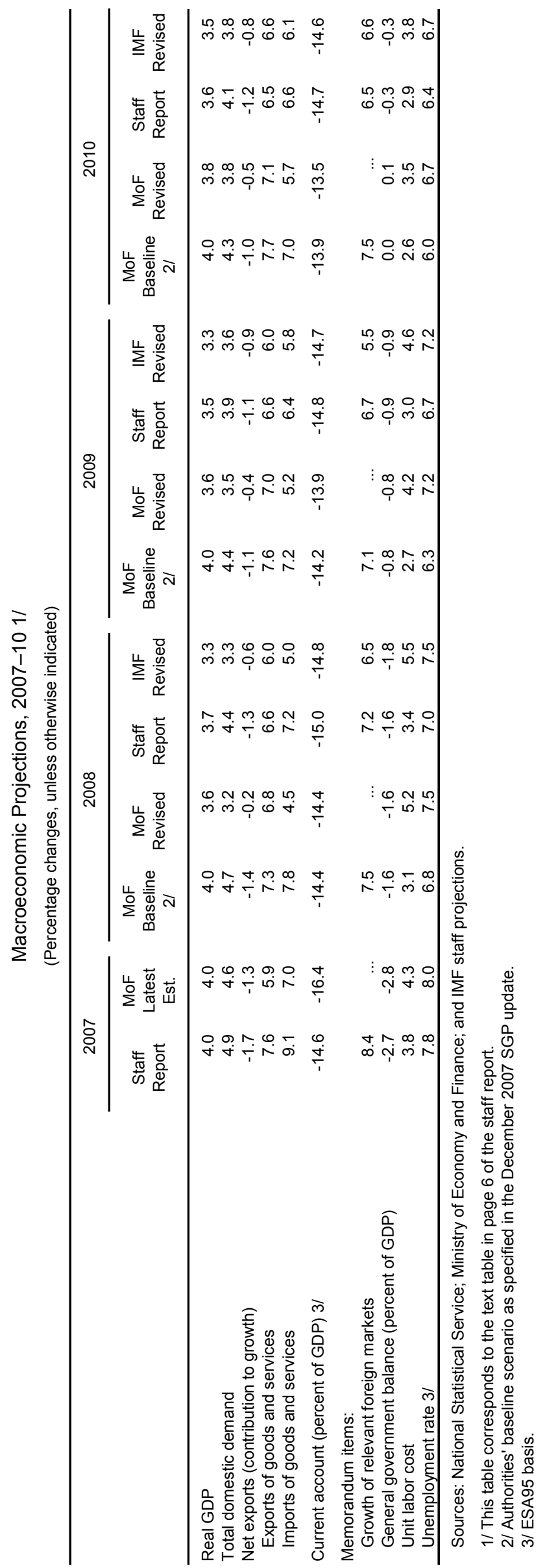


Greece: Revised Medium-Term Baseline Scenario, 2008-13 1/

\begin{tabular}{|c|c|c|c|c|c|c|}
\hline & 2008 & 2009 & 2010 & 2011 & 2012 & 2013 \\
\hline & \multicolumn{6}{|c|}{ Projection } \\
\hline Domestic economy & \multicolumn{6}{|c|}{ (Percentage change) } \\
\hline Real GDP & 3.3 & 3.3 & 3.5 & 3.5 & 3.5 & 3.5 \\
\hline Output gap & 1.8 & 1.2 & 0.9 & 0.5 & 0.3 & 0.0 \\
\hline Total domestic demand & 3.3 & 3.6 & 3.8 & 3.8 & 3.8 & 3.8 \\
\hline Private consumption & 3.0 & 3.0 & 3.0 & 3.0 & 3.0 & 3.0 \\
\hline Public consumption & 0.2 & 1.0 & 1.2 & 1.2 & 1.2 & 1.2 \\
\hline Gross fixed capital formation & 5.8 & 6.6 & 7.0 & 7.0 & 7.0 & 7.0 \\
\hline Foreign balance (contribution) 2/ & -0.6 & -0.9 & -0.8 & -0.9 & -0.9 & -1.0 \\
\hline Exports of goods and services & 6.0 & 6.0 & 6.6 & 6.7 & 6.6 & 6.6 \\
\hline Imports of goods and services & 5.0 & 5.8 & 6.1 & 6.2 & 6.1 & 6.3 \\
\hline Unemployment rate (percent) $2 /$ & 7.5 & 7.2 & 6.7 & 6.5 & 6.7 & 6.9 \\
\hline Employment 2/ & 1.2 & 1.2 & 1.3 & 1.2 & 0.8 & 0.7 \\
\hline Unit labor costs (economy wide) & 5.5 & 4.6 & 3.8 & 3.5 & 3.0 & 2.6 \\
\hline Consumer prices (HICP), end of period & 3.0 & 2.8 & 2.6 & 2.5 & 2.5 & 2.5 \\
\hline Consumer prices (HICP), period average & 3.7 & 2.8 & 2.6 & 2.5 & 2.5 & 2.5 \\
\hline GDP deflator & 3.7 & 3.0 & 2.8 & 2.7 & 2.6 & 2.6 \\
\hline External sector & \multicolumn{6}{|c|}{ (Percent of GDP) } \\
\hline Current account & -13.2 & -13.4 & -12.9 & -11.8 & -11.3 & -11.2 \\
\hline Trade balance & -10.6 & -10.6 & -10.1 & -8.9 & -8.3 & -8.2 \\
\hline Exports of goods and services & 22.5 & 22.6 & 22.6 & 22.4 & 22.4 & 22.6 \\
\hline Imports of goods and services & 33.1 & 33.2 & 32.7 & 31.3 & 30.7 & 30.8 \\
\hline Current transfers & 1.4 & 1.5 & 1.5 & 1.6 & 1.6 & 1.6 \\
\hline Net income receipts & -4.0 & -4.2 & -4.3 & -4.5 & -4.5 & -4.6 \\
\hline \multicolumn{7}{|l|}{ Public finances (general government) } \\
\hline Total revenues & 41.0 & 42.0 & 42.7 & 42.5 & 42.4 & 42.5 \\
\hline Total expenditures & 42.8 & 42.9 & 43.0 & 42.7 & 42.5 & 42.5 \\
\hline Primary expenditures & 38.7 & 38.9 & 39.1 & 39.0 & 38.9 & 39.1 \\
\hline Interest expenditures & 4.1 & 4.0 & 3.9 & 3.8 & 3.6 & 3.4 \\
\hline Overall balance & -1.8 & -0.9 & -0.3 & -0.3 & -0.1 & 0.0 \\
\hline Primary balance & 2.3 & 3.1 & 3.6 & 3.5 & 3.5 & 3.4 \\
\hline Structural overall balance (percent of potential output) & -2.6 & -1.5 & -0.7 & -0.5 & -0.3 & 0.0 \\
\hline Structural primary balance (percent of potential output) & 1.6 & 2.6 & 3.2 & 3.3 & 3.3 & 3.4 \\
\hline Gross debt & 91 & 88 & 84 & 80 & 76 & 72 \\
\hline \multicolumn{7}{|l|}{ Memorandum item: } \\
\hline Nominal GDP (billions of euros) & 245 & 261 & 277 & 295 & 313 & 333 \\
\hline
\end{tabular}

Sources: National Statistical Service; Ministry of Economy and Finance; Bank of Greece; and IMF staff estimates.

$1 /$ This table corresponds to table 3 in the staff report.

2/ ESA95 basis. 
Greece: Revised Summary of Balance of Payments, 2008-13 1/ (Percent of GDP)

\begin{tabular}{|c|c|c|c|c|c|c|}
\hline & 2008 & 2009 & 2010 & 2011 & 2012 & 2013 \\
\hline & \multicolumn{6}{|c|}{ Projection } \\
\hline Current account balance & -13.2 & -13.4 & -12.9 & -11.8 & -11.3 & -11.2 \\
\hline Balance of goods and services & -10.6 & -10.6 & -10.1 & -8.9 & -8.3 & -8.2 \\
\hline Goods balance & -18.7 & -18.9 & -18.4 & -17.4 & -16.9 & -16.9 \\
\hline Services balance & 8.1 & 8.2 & 8.3 & 8.4 & 8.6 & 8.7 \\
\hline Income balance & -4.0 & -4.2 & -4.3 & -4.5 & -4.5 & -4.6 \\
\hline Current transfers & 1.4 & 1.5 & 1.5 & 1.6 & 1.6 & 1.6 \\
\hline $\begin{array}{l}\text { Capital and financial account balance } \\
\text { Of which: }\end{array}$ & 13.2 & 13.4 & 12.9 & 11.8 & 11.3 & 11.2 \\
\hline Direct investment & 0.1 & 0.2 & 0.1 & 0.1 & 0.1 & 0.1 \\
\hline Portfolio investment & 3.4 & 3.4 & 3.2 & 2.9 & 2.8 & 2.6 \\
\hline Other investment & 8.3 & 8.4 & 8.2 & 7.3 & 6.9 & 7.1 \\
\hline External debt & 123.1 & 126.7 & 129.7 & 131.6 & 132.9 & 134.1 \\
\hline
\end{tabular}

Sources: Bank of Greece; and IMF staff projections.

$1 /$ This table corresponds to table 4 in the staff report. 
Public Information Notice (PIN) No. 08/49 FOR IMMEDIATE RELEASE April 30, 2008
International Monetary Fund $70019^{\text {th }}$ Street, NW

Washington, D. C. 20431 USA

\section{IMF Executive Board Concludes 2007 Article IV Consultation with Greece}

On April, 18, 2008, the Executive Board of the International Monetary Fund (IMF) concluded the Article IV consultation with Greece. ${ }^{1}$

\section{Background}

The Greek economy has been buoyant for several years, supported by solid gains in employment, substantial real wage increases, low interest rates, and rapid credit expansion. In 2007 , real GDP rose by an estimated 4 percent driven by domestic demand, but the external sector was a drag on growth. ${ }^{2}$ After peaking in 2004, the fiscal deficit fell sharply to under 3 percent of GDP in 2006 and was contained at 2.8 percent of GDP in 2007 despite several unexpected one-off expenditures amounting to about 1 percent of GDP. Nevertheless, the level of government debt, at 94 percent of GDP, remains high. Private sector credit has risen rapidly but household indebtedness is still relatively low. Inflationary pressures and rising labor costs have resulted in a steady deterioration in competitiveness, contributing to a large current account deficit of 13.9 percent of GDP.

Economic growth is expected to moderate in the near term but should remain solid on the back of continued strong domestic demand. However, the risks to the outlook are tilted to the downside. In the near term, risks stem from a weaker external environment and a potential liquidity squeeze of banks. Over the longer term, a persistent loss of competitiveness raises the risk of a prolonged period of slow growth.

\footnotetext{
${ }^{1}$ Under Article IV of the IMF's Articles of Agreement, the IMF holds bilateral discussions with members, usually every year. A staff team visits the country, collects economic and financial information, and discusses with officials the country's economic developments and policies. On return to headquarters, the staff prepares a report, which forms the basis for discussion by the Executive Board. At the conclusion of the discussion, the Managing Director, as Chairman of the Board, summarizes the views of Executive Directors, and this summary is transmitted to the country's authorities.
}

${ }^{2}$ A revision of the national accounts data was completed recently, raising the level of output in 2000 by 9.6 percent. 
The authorities are pursuing further fiscal consolidation with the goal of achieving a balanced budget by 2010 . The 2008 budget aims to reduce the general government deficit to 1.6 percent of GDP through ambitious revenue measures. However, the expenditure structure is set to become more rigid as the elimination of the one-off expenditures incurred in 2007 will be offset by higher outlays on wages and social transfers. The authorities are proceeding with a narrowly focused agenda on pension reform, which is nonetheless already drawing considerable protest.

The banking sector appears to be sound and has thus far remained largely unaffected by the global financial market turmoil. However, continued rapid credit growth and increasing presence in southeastern Europe, financed partly by wholesale funding, have increased banks' exposure to credit, country, and liquidity risks. The Bank of Greece has responded to these risks by increasing provisioning requirements, seeking a tightening of lending standards, and stepping up cross-border banking supervision.

The authorities have introduced a number of structural reforms to improve labor and product markets. These include easing overtime restrictions, reducing disincentives to accept employment, a new bankruptcy code, an updated company law, and simplified licensing of manufacturing businesses. More initiatives are in the works including reducing administrative burdens and improving the quality of services provision. Nevertheless, the Greek labor market is relatively rigid by international comparison and competition in product markets remains a challenge.

\section{Executive Board Assessment}

Executive Directors welcomed the extended period of strong performance of the Greek economy, which has significantly narrowed the gap in real per capita income between Greece and the EU-15. Directors considered that, while economic prospects still appear relatively strong in the near term, risks to the outlook are tilted to the downside, given the weaker external environment and the deterioration of global financial conditions. Directors also underscored that a persistent loss of cost competitiveness risks constraining Greece's growth in the medium term. Against this background, they encouraged the authorities to build the social consensus needed to undertake more ambitious medium-term reforms.

Directors observed that the banking system appears sound and has remained unaffected by the recent financial market turbulence to date. Nevertheless, financial sector vulnerabilities, including those arising from continued rapid credit growth, rising exposures in southeastern Europe, the still-high level of nonperforming loans, and possible need to rely on wholesale funding will require close monitoring. In this context, Directors welcomed the Bank of Greece's efforts to strengthen provisioning requirements and lending standards, and called for upgrading the stress-testing framework. Directors particularly welcomed steps to strengthen cross-border banking supervision in cooperation with other supervisors in southeastern Europe. They also commended the authorities for the adoption of a risk-based approach to supervision by the new insurance supervisor.

Directors welcomed the authorities' intention to achieve a balanced budget by 2010 , and considered that further improvements in tax administration and a tighter control over spending will be necessary to attain this target. Sustained fiscal consolidation thereafter to a surplus position will be helpful for safeguarding debt sustainability and addressing the prospective large aging costs. Directors called for the development of a medium-term budget framework to help guide fiscal strategy and prioritize policy objectives. 
Improved revenue collection will be a centerpiece of fiscal consolidation in 2008 and beyond. Directors saw scope for broadening tax reform. Improving tax compliance by simplifying tax laws and procedures and further intensifying risk-based auditing should be a priority. Directors also encouraged the authorities to consider phasing out distortionary tax exemptions with a view to broadening the tax base and simplifying the rate structure.

Directors emphasized the need for further reforms to expenditure management. They welcomed the steps already taken to increase the transparency and accountability of public entities and to improve efficiency in the health care system. Additional budget reforms should include extension of the coverage of the budget, full integration of program-based budgeting into budget preparation and execution, and introduction of appropriate financial management information systems.

Directors agreed that comprehensive reform of the social security system will be required to preserve the long-term sustainability of the public finances taking into account the costs of population aging. They considered that the authorities' pension reform agenda will need to be broadened, with policy proposals based on a full assessment of financing needs and cost savings. Directors encouraged the authorities to complete and publish detailed projections of the cost of population aging in accordance with the EU methodologies, and to prepare an adequately ambitious reform program on this basis.

Directors saw further reforms to product and labor markets as key to sustaining medium-term growth and strengthening international competitiveness. They welcomed the progress already made in product market reform, and encouraged the authorities to press ahead with further measures. Areas for action include further extension of simplified business licensing procedures, privatization of infrastructure facilities, and strengthened competition in the network industries and the transport sector. Further initiatives in the labor market should include reducing the restrictiveness of the employment protection legislation and increasing the flexibility of the wage setting system. Directors stressed the importance of further steps to improve the quality of statistical data.

Public Information Notices (PINs) form part of the IMF's efforts to promote transparency of the IMF's views and analysis of economic developments and policies. With the consent of the country (or countries) concerned, PINs are issued after Executive Board discussions of Article IV consultations with member countries, of its surveillance of developments at the regional level, of post-program monitoring, and of ex post assessments of member countries with longer-term program engagements. PINs are also issued after Executive Board discussions of general policy matters, unless otherwise decided by the Executive Board in a particular case. 
Greece: Selected Economic Indicators, 2001-08

(Annual percentage change; unless otherwise indicated)

\begin{tabular}{|c|c|c|c|c|c|c|c|c|}
\hline & 2001 & 2002 & 2003 & 2004 & 2005 & 2006 & 2007 & 2008 \\
\hline & & & & & & \multicolumn{2}{|c|}{ Estimate } & Proj. \\
\hline \multicolumn{9}{|l|}{ Real economy } \\
\hline Real GDP & 4.5 & 3.9 & 5.0 & 4.6 & 3.8 & 4.2 & 4.0 & 3.3 \\
\hline Total domestic demand & 2.6 & 5.1 & 6.6 & 4.9 & 3.0 & 5.4 & 4.3 & 3.3 \\
\hline Private consumption & 4.5 & 4.2 & 5.0 & 4.7 & 4.2 & 4.2 & 3.2 & 3.0 \\
\hline Public consumption & 0.4 & 7.3 & -1.0 & 2.7 & 1.4 & -0.7 & 8.7 & 0.2 \\
\hline Gross fixed capital formation & 4.1 & 10.7 & 15.4 & 6.0 & 0.7 & 14.8 & 4.4 & 5.8 \\
\hline Foreign balance (contribution) & 1.5 & -1.7 & -2.4 & -1.1 & 0.4 & -2.0 & -1.3 & -0.6 \\
\hline Unemployment rate (percent) $1 /$ & 10.4 & 9.9 & 9.4 & 10.2 & 9.5 & 8.6 & 8.0 & 7.5 \\
\hline Employment $1 /$ & 0.2 & 2.0 & 1.9 & 0.9 & 1.5 & 2.5 & 1.3 & 1.2 \\
\hline Unit labor costs (economy wide) & 2.9 & 3.2 & 1.4 & 4.9 & 3.7 & 3.3 & 4.3 & 5.5 \\
\hline GDP deflator & 2.7 & 3.7 & 3.5 & 3.4 & 3.3 & 3.4 & 2.9 & 3.7 \\
\hline \multirow{2}{*}{\multicolumn{9}{|c|}{ Public finance (percent of GDP) }} \\
\hline & & & & & & & & \\
\hline General government balance & -4.5 & -4.7 & -5.6 & -7.4 & -5.1 & -2.6 & -2.8 & -1.8 \\
\hline General government primary balance & 2.0 & 0.7 & -0.7 & -2.4 & -0.8 & 1.4 & 1.2 & 2.3 \\
\hline \multicolumn{9}{|l|}{ General government structural balance (percent } \\
\hline of potential output) & -4.7 & -5.0 & -6.3 & -8.5 & -6.2 & -3.7 & -3.9 & -2.6 \\
\hline General government gross debt & 104 & 101 & 98 & 99 & 98 & 95 & 94 & 91 \\
\hline \multicolumn{9}{|l|}{ Money and credit (end of year, percent change) } \\
\hline Domestic credit & 9.3 & 8.5 & 3.0 & 10.3 & 17.0 & 14.5 & 14.4 & $\ldots$ \\
\hline \multicolumn{9}{|l|}{ Interest rates (percent) } \\
\hline Deposit rate & 3.3 & 2.8 & 2.5 & 2.3 & 2.2 & 2.9 & 4.5 & $\ldots$ \\
\hline Government bond yield & 5.3 & 5.1 & 4.3 & 4.3 & 3.6 & 4.1 & 4.5 & $\ldots$ \\
\hline \multicolumn{9}{|l|}{ Balance of payments (percent of GDP) } \\
\hline Exports of goods and services & 23.0 & 20.0 & 19.0 & 21.3 & 20.9 & 20.8 & 21.2 & 22.5 \\
\hline Imports of goods and services & 31.5 & 27.6 & 25.5 & 26.7 & 27.0 & 30.1 & 31.9 & 33.1 \\
\hline Trade balance & -8.5 & -7.6 & -6.5 & -5.4 & -6.1 & -9.3 & -10.7 & -10.6 \\
\hline Current account & -7.2 & -6.5 & -6.4 & -5.8 & -7.4 & -11.0 & -13.9 & -13.2 \\
\hline \multicolumn{9}{|l|}{ Exchange rate } \\
\hline Exchange rate regime & & & & & & Euro a & rea & \\
\hline Present rate (April 18, 2008) & & & & & & 0.63 & & \\
\hline Nominal effective exchange rate $(1990=100)$ & 101.3 & 103.6 & 109.3 & 110.9 & 110.3 & 110.5 & 113.9 & ... \\
\hline Real effective exchange rate $(1990=100)$ & 101.2 & 104.3 & 111.1 & 113.0 & 113.6 & 114.6 & 118.8 & $\ldots$ \\
\hline
\end{tabular}

Sources: National Statistical Service; Ministry of Economy and Finance; Bank of Greece; IMF, World Economic Outlook; and IMF staff estimates and projections.

1/ Data are ESA95 basis. 


\section{Statement by Miranda Xafa, Alternate Executive Director for Greece April 18, 2008}

I would like to express my authorities' appreciation to Mr. Banerjee, the mission chief, and his able team for the fruitful discussions they have had during this year's Article IV consultation and for their excellent report. The authorities broadly agree with staff's analysis and recommendations, including on the challenges in the years ahead.

\section{The policy setting}

1. Three years ago, during the 2004 Article IV consultation, staff noted that the strong growth of the Greek economy was partly due to a favorable external environment and to exceptional factors, including joining the Euro-area and hosting of the 2004 Olympic Games. They expressed concern that growth would decline as the impact of these factors waned. Luckily this concern - which was shared by the authorities - did not materialize. Growth became more sustainable in the past three years through a shift away from debt-financed expansionary fiscal policy toward supply-side reforms aimed at increasing productivity and potential growth. GDP growth averaged 4 percent in 2005-07, led by strong exports and buoyant business fixed investment. Private investment has been supported by lower corporate tax rates, investment incentives, public-private partnerships, and an improvement in the business climate. These policies succeeded in sustaining the growth momentum and reducing unemployment despite substantial fiscal tightening.

2. The December 2007 update of the Stability and Growth Program projected robust GDP growth of 4 percent to be sustained in 2008-09. However, new challenges have arisen from the credit crunch that has impacted financial stability and growth globally. Recognizing the negative spillovers from a weaker external environment and soaring commodity prices, the official estimate of GDP growth was revised to 3.6 percent in 2008 and 2009, and the inflation forecast for 2008 was raised to 3.5 percent from 2.8 percent previously. These revised projections are marginally less pessimistic than those presented in the Staff Supplement, reflecting a somewhat more buoyant external environment.

\section{Fiscal policy}

3. Fiscal consolidation advanced significantly in 2006-07, bringing the general government deficit below the 3 percent of GDP threshold, in line with the commitment under the EU Excessive Deficit Procedure. This was achieved through spending restraint and improved tax administration, while personal and corporate tax rates were cut. Following a cut in the corporate tax rate to 25 percent, marginal tax rates on personal income - especially for middle incomes - are being reduced over two years in 2008-09. Indirect tax revenues rose 
faster than GDP in 2007, providing evidence that measures to combat tax evasion are working.

4. Despite the weaker growth outlook, the fiscal targets for 2008 have not been revised as the authorities see no room for countercyclical easing. The deficit is budgeted to decline to 1.6 percent of GDP in 2008, in line with the Government's objective of achieving a balanced budget by $2010 .{ }^{1}$ On a cyclically adjusted basis the deficit is budgeted to decline to 2.5 percent of GDP in 2008, down from 3.5 percent in 2007 and 3.3 percent in 2006, i.e. by a cumulative total of 0.8 percent of GDP in 2006-08. The adjustment effort is larger than suggested by these figures as the budget no longer relies on one-off revenue measures, while the 2007 budget includes emergency assistance of 0.5 percent of GDP following last summer's wildfires. Moreover, the 2008 cyclical component is currently being revised to reflect the downward revision of GDP growth projections. Efforts to restrain expenditure in 2008 have been supported by new legislation governing fiscal audits and controls. So far, controls only referred to the compliance of public spending with the Budget Law. Under the new system, a General Directorate for Fiscal Audits is established along with internal audit units within Ministries, local authorities and public entities with a budget exceeding $€ 3$ million. The Directorate is expected to propose corrective measures whenever necessary to keep total spending in line with the Budget. Improved budgetary procedures, including program-based budgeting, are expected to improve the transparency, efficiency and control of public expenditure in the medium term.

5. On the revenue side, property taxes are being reformed to broaden the tax base, and new measures were adopted to fight tax evasion. Under a new law adopted last January, several property levies are being merged into a single property tax of 0.1 percent payable annually. To clamp down on tax evasion in fuel oils, the special consumption tax on motor fuel was extended to heating oil, with consumers eligible for a full refund of the additional tax. A National Committee for tackling tax evasion has been established, consisting of representatives of the social partners and political parties in Parliament. The Committee will submit proposals for measures to improve tax compliance and provide better service to taxpayers. In parallel, staff recommendations for broadening the tax base (Selected Issues paper II) will be examined by the newly-established Tax Analysis Unit at the Ministry of Economy and Finance and a proposal will be submitted to the Minister.

\footnotetext{
${ }^{1}$ All ratios are calculated on the basis of revised GDP figures, which exceed the old series by almost 10 percent. The revised GDP series was made possible by new primary sources of information that resulted in significant upward revisions of output in the construction and services sectors. Efforts to strengthen national account statistics are ongoing, as newlyintroduced surveys are regularly conducted. In future, re-benchmarking will be undertaken on a regular basis to avoid large revisions.
} 


\section{Public debt}

6. Fiscal consolidation has contributed to a decline in the public debt burden from 98.6 percent of GDP in 2004 to 94.5 percent in 2007. Strong growth, privatization revenue and primary surpluses contributed to the decline, although the assumption of liabilities of the broader public sector added to the debt burden. Going forward, it is critical that public enterprises and entities face harder budget constraints. Some of these continue to operate while generating losses and accumulating arrears or defaulting on government-guaranteed debt. A law was already passed in November 2005 that aims to increase the commercial orientation of public enterprises and streamline their operations to reduce their reliance on debt guarantees and budget transfers. The government also is planning to introduce greater transparency and accountability in the operations and finances of local governments, public hospitals and pension funds.

\section{Pension reform}

7. A pension reform law was approved by Parliament at end-March, triggering a wave of protests. The reform aims at streamlining the administration of the pension system and contributing to its long-term sustainability. The state-run, PAYG pension system suffers both from extreme fragmentation and from a rising dependency ratio due to population aging. The reform provides for a mega-merger of more than 100 separate funds into 13 main or supplementary funds. While the statutory age of 65 for men and women remains unchanged, the reform of early retirement provisions, along with incentives to prolong working life, would tend to move the average effective retirement age, currently at 61 , closer to the statutory age of 65 . The reform is expected to produce savings from both administrative costs and from changes in early retirement provisions. Savings also will accrue from the imposition of a limit on supplementary pensions to 20 percent of pensionable earnings. The main impact of these measures will be felt from 2013, when the transition periods start expiring. Total savings from the reform during the first two years are officially estimated at some $€ 2$ billion, of which $€ 1.5$ billion from administrative cost savings and the rest from changes in early retirement provisions and supplementary pensions, compared with pension expenditures currently amounting to $€ 24$ billion annually (12.5 percent of GDP). The bulk of administrative savings would accrue from the pooling of pension fund reserves into a single asset management entity. Greater transparency and accountability would be introduced by a committee that will audit and control the pension funds.

8. A key provision of the pension reform law is the creation of an intergenerational Social Solidarity Fund to safeguard the pensions of future generations. The Fund's resources will be derived from several annual revenue streams: 10 percent of privatization revenue, 4 percent of VAT revenues, and 10 percent of the earmarked taxes accruing to existing pension funds. In its first year of operation in 2009, the fund is expected to collect about $€ 900$ million in revenues $(0.3$ percent of GDP). 


\section{Competitiveness and the external sector}

9. Greek exports have performed well in recent years, despite a persistently high inflation differential with the Euro area that suggests declining price competitiveness. As highlighted in the Selected Issues paper I, this strong performance reflects quality upgrades, export specialization in high value-added services, and geographical orientation toward the fastgrowing Balkan markets. The focus on the Balkans - and Eastern Europe more broadly - has made Greece one of the EU countries that have benefited the most from the transition in that region and from the entry of Bulgaria and Romania into the EU in 2007. Greece's early economic and financial links with this fast-growing region through trade and direct investment are thus paying off. Nevertheless, there is a clear risk that the ongoing financial turbulence could slow externally-funded credit expansion and growth in the region, adversely affecting Greece through both trade and financial links.

10. The widening of the current account deficit over the past decade is largely explained by factors other than competitiveness. As Greece liberalized its financial system later than other euro area countries, the demand stimulus from consumption smoothing coincided with the stimulus from interest rate convergence in the run-up to EMU and from subsequent ECB easing. The resulting surge in investment was accompanied by a fall in the savings ratio, as financial liberalization reduced precautionary savings. Consumer and housing credit became readily available at constantly falling rates, giving a big boost to domestic demand. As this process winds down, the current account deficit will narrow. There is little policy makers can do to correct the deficit besides continuing the fiscal consolidation path and implementing supply-side reforms to raise productivity. The authorities share the staff's view that structural reforms have an important role to play in safeguarding competitiveness and raising potential growth. To this end, they are already implementing reforms to strengthen competition in product markets, facilitate the spread of ICT, improve the business climate, and promote flexibility in labor markets. Further improvements in these areas remain essential to accelerate real convergence.

\section{Financial sector issues}

11. Greek banks remained well-capitalized and highly profitable in 2007, suggesting that the impact of the financial market turmoil has so far been minimal. Regulatory capital to riskweighted assets amounted to 12.7 percent at end-2007, well above the required minimum, while ROE rose to 14.8 percent in 2007 from 12.8 percent in 2006. The Bank of Greece calculates the total losses due to the turmoil at 0.7 percent of capital, of which 0.3 percent derived from revaluation of securities directly affected from the turmoil and 0.4 percent from higher funding costs. These modest losses reflect the negligible exposure of Greek banks to the U.S. subprime mortgage sector, and the fact that Greek banks had taken advantage of benign financial market conditions prior to the crisis to pre-fund their operations until mid2008. Rapid credit growth and persistently high NPLs led to increased write-offs and 
improved risk monitoring by banks as they transition from Basel I to Basel II. As a result, NPLs were reduced from 5.4 percent of total loans at end-2006 to 4.5 percent at end-2007.

12. Recognizing that funding and roll-over risk could become elevated if the crisis were prolonged, the BoG conducted stress tests specifically designed to address liquidity concerns. Banks were asked to calculate their Liquid Assets Ratios (LAR) for mid-2008 on the assumption that their business expansion plans were fully implemented. In the event this ratio fell below 20 percent under various stress scenaria, they were given the option of scaling back their credit expansion or raising additional funding to restore the required minimum LAR. Despite the grid lock in securitization markets, Greek banks have so far made very limited use of the ECB discount window to raise funding using mortgage-backed securities as collateral. Regarding the exposure of Greek banks operating in the Balkans, efforts underway to take into account the correlation of FX and credit risk, as suggested by staff, are complicated by lack of data. 